\title{
Lake Michigan's suitability for bigheaded carp: The importance of diet flexibility and subsurface habitat
}

\author{
Peter J. Alsip ${ }^{1,2}$ (D) | Hongyan Zhang ${ }^{3}$ | Mark D. Rowe ${ }^{4}$ | Doran M. Mason ${ }^{4}$ | \\ Edward S. Rutherford ${ }^{4}$ | Catherine M. Riseng ${ }^{1}$ | Zhenming Su ${ }^{5}$
}

${ }^{1}$ School for Environment and Sustainability, University of Michigan, Ann Arbor, Michigan, U.S.A

${ }^{2}$ Cooperative Institute for Great Lakes Research, University of Michigan, Ann Arbor, Michigan, U.S.A

${ }^{3}$ Eureka Aquatic Research, LLC., Ann Arbor, Michigan, U.S.A

${ }^{4}$ Great Lakes Environmental Research Laboratory, National Oceanic and Atmospheric Administration, Ann Arbor, Michigan, U.S.A

${ }^{5}$ Michigan Department of Natural Resources, Institute for Fisheries Research, University of Michigan, Ann Arbor, Michigan, U.S.A

\section{Correspondence}

Peter J. Alsip, School for Environment and Sustainability, University of Michigan, Ann Arbor, MI, U.S.A.

Email: peterals@umich.edu

Funding information

Michigan Sea Grant Graduate Research Fellowship, Grant/Award Number: NA14OAR4170070; Michigan Department of Natural Resources

\section{Abstract}

1. As bighead (Hypophthalmichthys nobilis) and silver carp (Hypophthalmichthys molitrix)-collectively bigheaded carp (BHC)-arrive at Lake Michigan's doorstep, questions remain as to whether there is sufficient food to support these invasive filter-feeding fishes in the upper Laurentian Great Lakes. Previous studies suggest that suitable BHC habitat is limited to a few productive, nearshore areas. However, those studies did not consider the influence of $\mathrm{BHC}^{\prime}$ s diet plasticity or the presence of spatially-discrete subsurface prey resources. This study aimed to characterise Lake Michigan's suitability for BHC and evaluate the importance of these considerations in habitat suitability assessments.

2. We used simulated outputs of prey biomass (phytoplankton, zooplankton, and detritus) and water temperature from a three-dimensional biophysical model of Lake Michigan to evaluate growth rate potential (GRP, quantitative index of habitat suitability) of adult BHC throughout the entire volume of the lake. Our GRP model applied a foraging model and a bioenergetics model to translate prey concentrations and water temperatures into habitat quality indexed by individual fish growth rate. We defined suitable habitat as habitats that can support GRP $\geq 0 \mathrm{~g} \mathrm{~g}^{-1} \mathrm{day}^{-1}$. We developed six feeding scenarios to evaluate the impact of diet flexibility and subsurface prey resources on suitable habitat quantity. Scenarios were defined by the number of prey types the fish could consume and the depths at which they could feed (surface or whole water column).

3. Consistent with previous studies, we found that habitats with the highest quality were concentrated near river mouths and in eutrophic areas of Green Bay. However, in contrast to previous studies, we found suitable offshore habitat for bighead carp owing to our added considerations of diet plasticity and subsurface prey resources. For silver carp, these considerations extended suitable habitat within Green Bay and in some tributary-influenced nearshore areas, but offshore areas remained predominantly unsuitable in all feeding scenarios. Differences in simulated habitat suitability between these two species probably reflect differences in energy density and mass of the specific fishes we used in our model. However, reports of these two species in environments where they coexist indicate that bighead carp grow at faster rates than silver carp, as our model simulated. 
4. Our vertical analysis at Muskegon, MI, U.S.A. indicates that subsurface temperature and prey biomass are not only sufficient to support bighead carp growth but provide maximum habitat quality during late summer stratification.

5. Overall, our study demonstrates that $\mathrm{BHC}$ are capable of surviving and growing in much larger areas of Lake Michigan than predicted by previous studies, and thus suggests that the risk of establishment is not sufficiently reduced by low plankton concentrations. Maps generated by our model identified the potential for crosslake migration corridors that may facilitate and accelerate lake-wide movements. We believe these maps could be used to prioritise surveillance protocols by identifying areas to which $\mathrm{BHC}$ might spread upon entering the lake. More broadly, this research demonstrates how the physiology and trophic ecology of BHC contributes to their high invasive capacity and can permit their survival in novel environments.

\section{KEYWORDS}

Asian carp, growth rate potential, habitat suitability, invasive species, Laurentian Great Lakes

\section{1 | INTRODUCTION}

The ecological history of the Laurentian Great Lakes post-European settlement is arguably best known for the intentional and unintentional introduction of aquatic non-indigenous species. However, of the 180+ established non-native species in the Great Lakes, only a few have become invasive (as defined by Executive Order 13112 in 1999). The undesirable, system-altering effects of the most notorious invaders, i.e. the sea lamprey (Petromyzon marinus) and the dreissenid mussels (the quagga mussel Dreissena rostriformis bugensis and zebra mussel Dreissena polymorpha), have contributed to the decline of ecologically and recreationally important native species, altered trophic dynamics, influenced patterns of productivity, and imposed significant socioeconomic burdens (Hecky et al., 2004; Madenjian, Rutherford, Stow, Roseman, \& He, 2013; Nalepa, Fanslow, \& Lang, 2009; Rosaen, Grover, \& Spencer, 2012; Vanderploeg, Liebig, Nalepa, Fahnenstiel, \& Pothoven, 2010). As a result, stakeholders have become increasingly aware of the next major invader sitting on Lake Michigan's doorstep: bighead carp Hypophthalmichthys nobilis and silver carp Hypophthalmichthys molitrix (hereafter collectively referred to as bigheaded carp [BHC]) (International Joint Commission, 2018).

Bigheaded carp were imported to the U.S.A. in the 1970s to control eutrophication in reservoirs and sewage treatment lagoons (Kolar et al., 2007). Following their escape, these species quickly spread throughout the Mississippi River basin and have established dense populations in many of the reaches they have invaded, including the Illinois River where they comprise $63 \%$ of the total fish biomass (Garvey et al., 2015). The impact of BHC in these invaded ecosystems and the proximity of the invasion front to Lake Michigan have elevated concerns about a potential invasion into the Great Lakes via the Chicago Area Waterway System; the man-made connection between the Illinois River and Lake Michigan (ACRCC, 2016).

The effects of $\mathrm{BHC}$ on invaded ecosystems are often complex due to their capacity to directly and indirectly affect multiple trophic levels. Intensive grazing of plankton by BHC can reduce phytoplankton abundance in invaded habitats (Deboer, Anderson, \& Casper, 2018; Tumolo \& Flinn, 2017) and alter community composition by promoting the dominance of indigestible phytoplankton taxa (Görgényi et al., 2016). In turn, BHC can exert significant pressure on zooplankton through predation and by reducing the abundance of consumable food (Cooke, Hill, \& Meyer, 2009; Deboer et al., 2018; Radke \& Kahl, 2002; Sass et al., 2014). The decline in the body condition and populations of native planktivores in the Illinois and Upper Mississippi rivers has been largely attributed to the competitive interaction with BHC (Irons, Sass, McClelland, \& Stafford, 2007; Pendleton, Schwinghamer, Solomon, \& Casper, 2017; Sampson, Chick, \& Pegg, 2009). Hypothetically, BHC not only would compete with resident planktivores in the Great Lakes, but also with other fishes during their plankton-dependent larval stage. Interestingly, evidence from Deboer et al. (2018) showed no signs of silver carp having adverse effects on native larval fish biomass in the Illinois River. However, this interaction might differ in a food-limited environment like Lake Michigan. If BHC invade Lake Michigan, they could compete with an already-declining population of planktivorous prey fishes (Madenjian et al., 2012) for a limited prey supply (Vanderploeg et al., 2010, 2012) and could effect a trophic bottleneck that reduces the flow of energy to higher trophic levels (Irons et al., 2007).

The magnitude of potential BHC effects in Lake Michigan is contingent upon their ability to establish successfully. Establishment is a multi-faceted stage in the invasion process and a variety of approaches have been used to address the probability of BHC establishment in the Great Lakes (Anderson, Chapman, Wynne, 
Masagounder, \& Paukert, 2015; Cooke \& Hill, 2010; Cuddington, Currie, \& Koops, 2014; Kocovsky, Chapman, \& McKenna, 2012). Previous modelling efforts have determined that $\mathrm{BHC}$ establishment would not be limited by hydrologic and climatic conditions (Chen, Wiley, \& Mcnyset, 2007; Herborg, Mandrak, Cudmore, \& Maclsaac, 2007), and several Great Lakes tributaries have viable spawning habitats (Kocovsky et al., 2012; Kolar et al., 2007; Murphy \& Jackson, 2013). However, the capacity of the oligotrophic offshore waters of Lake Michigan to support invasive planktivores has generated scepticism around the likelihood of BHC establishment (Cooke \& Hill, 2010).

The oligotrophication of Lake Michigan that has occurred over the past 50 years has been linked to several factors including climatic variation, reduced phosphorous loads, and, perhaps most notably, the proliferation of the invasive quagga mussel (Rowe et al., 2017; Warner \& Lesht, 2015). The filtering activity of the invasive dreissenid mussels has contributed to major changes in Lake Michigan's lower trophic levels (Fahnenstiel, Nalepa, Pothoven, Carrick, \& Scavia, 2010). Some of the strongest effects include the disappearance of the spring phytoplankton bloom (Vanderploeg et al., 2010), the redirection of nutrients and the flow of energy to the nearshore (Hecky et al., 2004), and changes in size structure and species composition in zooplankton and phytoplankton communities (De Stasio, Schrimpf, \& Cornwell, 2014; Vanderploeg et al., 2012). The dreissenid invasion also has altered energy dynamics in alewives (Alosa pseudoharengus) and contributed to the declining biomass of planktivorous prey fishes in Lake Michigan (Madenjian, Pothoven, Dettmers, \& Holuszko, 2006; Madenjian et al., 2012). The reductions in plankton and planktivorous fish biomass suggest that $\mathrm{BHC}$ would probably be food-limited in most open water habitats of Lake Michigan. While the cold, less productive waters of Lake Michigan are probably not as conducive for $\mathrm{BHC}$ growth and survival than the productive rivers in their native and introduced ranges, the degree to which their establishment and spread are limited by these factors has only recently been investigated.

Recent evaluations of BHC habitat suitability have used bioenergetics models to determine Lake Michigan's capacity to support the growth of these invasive fishes (Anderson, Chapman, Wynne, \& Paukert, 2017; Cooke \& Hill, 2010). Bioenergetics models are particularly useful in this application because they can translate prey abundance and water temperatures into growth potential of BHC, thus highlighting where in Lake Michigan there is sufficient food and thermal conditions for an individual fish to maintain weight or grow. Cooke and Hill (2010) and Anderson et al. (2017) found that suitable habitat for $\mathrm{BHC}$ growth in Lake Michigan is limited to a few productive, nearshore areas, but they did not account for the fishes' flexible diet or evaluate habitat beneath the surface (>1 m). While BHC typically feed on phytoplankton or zooplankton, they are also opportunistic feeders that are capable of surviving on diets dominated by organic detritus and bacteria (Anderson, Chapman, \& Hayer, 2016; Chen, 1982; Kolar et al., 2007). Therefore, understanding how a BHC's diet plasticity influences their growth potential is an important next step for advancing our understanding of establishment risk.
Consideration of the temporal and three-dimensional (3-D) spatial complexities of Lake Michigan is also essential for quantifying habitat suitability. For example, a thermally stratified limnetic environment like Lake Michigan may offer opportunities for growth at depths that have yet to be assessed. Maximum growth rate at lower temperatures is attained when feeding at reduced rations (Hanson, Johnson, Schindler, \& Kitchell, 1997), and the presence of a deep chlorophyll layer (DCL) during summer stratification suggests that BHC may find sufficient food below Lake Michigan's surface (Bramburger \& Reavie, 2016; Pothoven \& Fahnenstiel, 2013). Given the potential energetic benefits of the $\mathrm{DCL}$, it seems likely that $\mathrm{BHC}$ could reside there to optimise their growth. Improving our understanding of establishment risk requires that all potential habitats in the lake be investigated and, therefore, habitat suitability assessments need to evaluate spatially explicit growth potential throughout the water column as well as across the entire extent of the lake.

We approached the question of establishment by evaluating the growth rate potential (GRP) (Brandt, Mason, \& Patrick, 1992) of BHC given habitat conditions (i.e. prey biomass and water temperatures) present in Lake Michigan. We used simulated prey abundance and temperature values from a 3-D biophysical model of Lake Michigan (Rowe, Anderson, Wang, \& Vanderploeg, 2015; Rowe et al., 2017). Our GRP model builds on the foundational work of Anderson et al. $(2015,2017)$ and Cooke and Hill $(2010)$ by evaluating Lake Michigan's habitat quality based on the biomass of three prey resources (phytoplankton, zooplankton, detritus) throughout the water column in Lake Michigan. Our research objectives were to: (1) elucidate how a flexible diet and the availability of subsurface prey influence the extent and quality of suitable BHC habitat in Lake Michigan; and (2) characterise the spatiotemporal dynamics of suitable habitat across the lake as well as vertically throughout the water column along a nearshore-offshore transect. We hypothesised that suitable habitat for $\mathrm{BHC}$ would increase in response to increases in the types of prey items in their diet and the availability of subsurface resources. We also hypothesised that the extent and quality of suitable habitat would fluctuate seasonally, and that suitable habitat existed beneath the surface (>1 m).

\section{2 | METHODS}

\section{1 | Study site}

Lake Michigan is a temperate, meso-oligotrophic lake with a surface area of about $57,800 \mathrm{~km}^{2}$, a mean depth of $85 \mathrm{~m}$, a maximum depth of $282 \mathrm{~m}$, and average summer surface temperatures that reach 21$22^{\circ} \mathrm{C}$ (NOAA Great Lakes CoastWatch Program, 2018) (Figure 1). Lake Michigan's biotic and abiotic environment is spatially heterogeneous and dynamic (Rowe et al., 2017). The lake is dimictic-mixing in the spring and autumn and thermally stratifying in the summer and winter. The formation of a thermocline during summer stratification divides the water column into three ecologically distinct zones: an epilimnion, metalimnion, and hypolimnion. Deep chlorophyll layers also occur during summer near the base of the metalimnion at an 


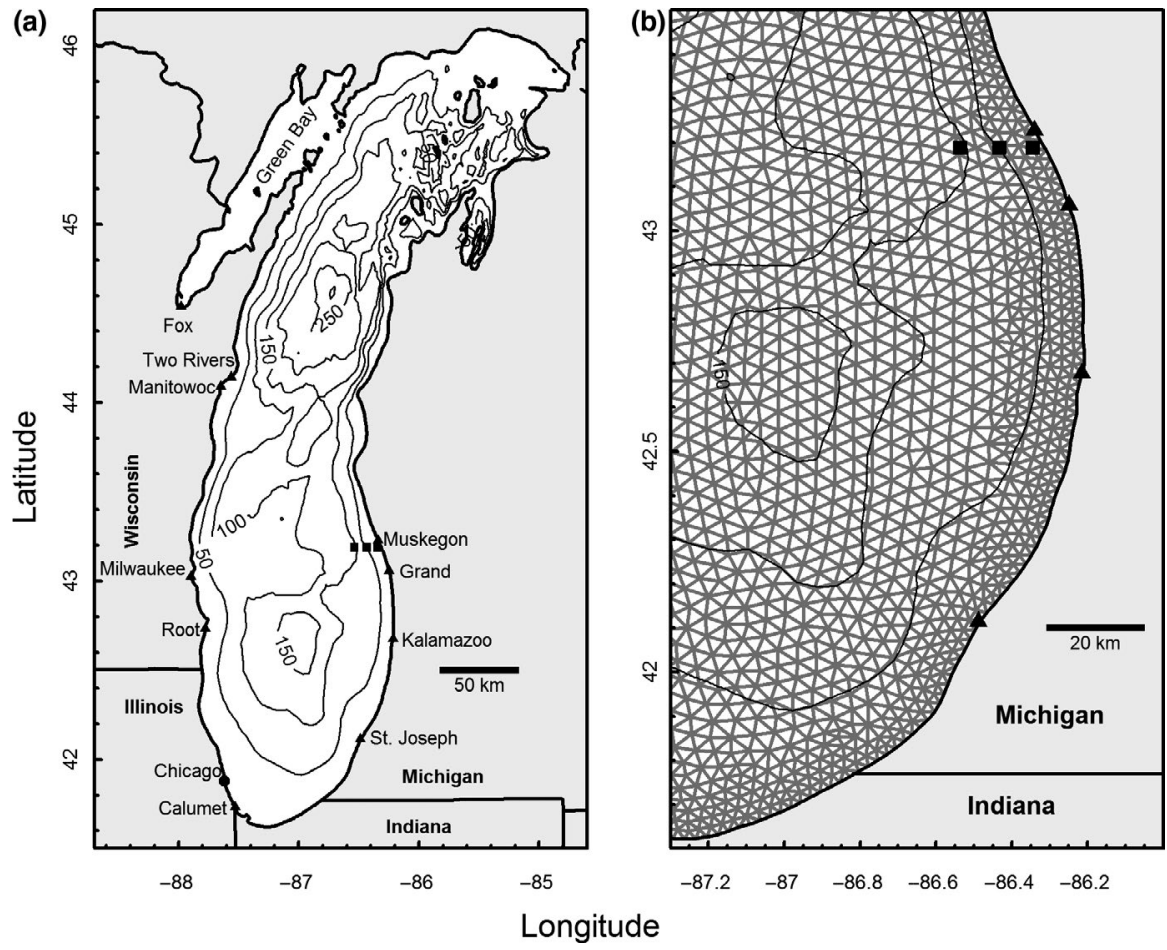

FIGURE 1 Map of Lake Michigan (a), showing the spatial domain of Finite Volume Community Ocean ModelGeneral Ecosystem Module (white area), bathymetry (50-m contours), bordering states (bolded names), tributary phosphorus loads at 38 locations (filled triangles) labelled by name, and National Oceanic and Atmospheric Administration stations along a nearshore-offshore gradient near Muskegon, MI (filled squares). Enlarged area of southeastern Lake Michigan (b), showing the hydrodynamic model grid, National Oceanic and Atmospheric Administration Muskegon stations (filled squares), and the location of four tributary mouths (filled triangles) average depth of $30 \mathrm{~m}$ (Bramburger \& Reavie, 2016). The lake exhibits a strong productivity gradient from nearshore to offshore, which has been amplified by the invasion of the dreissenid mussels (Hecky et al., 2004). Lake Michigan's large size, biophysical heterogeneity, and seasonal dynamics highlight the need for models that can consider $\mathrm{BHC}$ invasion risk in a spatially and temporally explicit context.

\section{2 | Model development and data source}

\subsection{1 | Growth rate potential model}

Growth rate potential models provide a quantitative metric for evaluating habitat quality by translating prey concentrations and environmental conditions (e.g. water temperature) into terms of fish biomass production as indexed by individual growth rate. Growth rate potential models have been developed for a variety of species in different systems (Brandt et al., 1992; Luo, Hartman, Brandt, Cerco, \& Rippetoe, 2001; Mason, Goyke, \& Brandt, 1995; Zhang et al., 2014). Our GRP model integrates three main components: (1) a bioenergetics model to estimate growth; (2) a foraging model to estimate consumption inputs for the bioenergetics model; and (3) a spatially explicit 3-D environment. The GRP model is constrained by speciesspecific physiological parameters and is driven by habitat conditions (i.e. temperature and prey concentrations) that were output from a spatially explicit biophysical model. All simulations were coded and run in R version 3.5.1 (https://CRAN.R-project.org).

\subsection{2 | Bioenergetics model}

We used the Wisconsin Fish Bioenergetics 3.0 model (Hanson et al., 1997), which uses a mass balance approach that estimates growth rate $\left(G, \mathrm{~g} \mathrm{~g}^{-1} \mathrm{day}^{-1}\right)$ of an individual by subtracting respiration $(R)$, egestion $(F)$, excretion $(U)$, and specific dynamic action $(S)$ from estimates of consumption $(C)$ :

$$
G=C-(R+F+U+S)
$$

To better compare our results with those from previous studies (Anderson et al., 2015, 2017; Cooke \& Hill, 2010), we adopted their bioenergetics equations and parameter values for consumption, respiration, egestion and excretion, initial fish mass, and predator and prey energy density (Tables S1.1 and S1.2). When these studies used different parameter values (e.g. consumption $C A, C B$; fish mass $W$; and predator energy density $E D_{\text {Carp }}$ ), we used the values from Anderson et al. (2015).

\subsection{3 | Foraging model}

We calculated $C$ by taking the minimum value of two consumption estimates: maximum consumption based on mass and temperature (Cmax, Table S1.2) and foraging-based consumption $\left(C_{\mathrm{FR}}\right)$. Cmax is determined by the bioenergetics equation for consumption whereas $C_{F R}$ is a function of temperature $(f(T))$, prey concentration $(g / L)$, and filtration rate (FR; L/day), which itself is a function of fish mass $W(g)$ and foraging hours ( $t$ ) (from Smith, 1989):

$$
C_{\mathrm{FR}}=\left(\mathrm{FR} * \frac{\text { (Phyto. conc. }+ \text { Zoopl. conc. }+ \text { Detritus conc.) }}{\mathrm{W}}\right) * f(T)(2)
$$

$$
\mathrm{FR}=1.54 * \mathrm{~W}^{0.713} * t
$$

We then multiplied the minimum value between $C_{\mathrm{FR}}$ and $C_{\max }$ by a prey-to-predator energy density $(E D)$ ratio to calculate $C$ $\left(\mathrm{g} \mathrm{g}^{-1}\right.$ day $\left.^{-1}\right)$ : 


$$
C=\min \left(C_{\max }, C_{\mathrm{FR}}\right) * \frac{E D_{\text {Prey }}}{E D_{\text {Carp }}}
$$

Bigheaded carp will feed opportunistically on a multiple prey types-often selecting for preferred prey when it is abundant and on less preferable prey when preferred prey is limited (Kolar et al., 2007). To account for this foraging behaviour, we assumed that the fish would aim to maximise its specific consumption rate, and only supplement their diet with detritus when favourable planktonic prey became limited (Supporting Information, S2).

\subsection{4 | Spatially explicit 3-D environment}

The 3-D, heterogeneous environment was defined by prey concentrations (phytoplankton, zooplankton, and detritus) and water temperatures simulated by the Lake Michigan Finite Volume Community Ocean Model-General Ecological Module (FVCOMGEM, Figure 1) (Rowe et al., 2015, 2017). FVCOM is a 3-D, hydrodynamic numerical model that predicts currents, temperature, and water levels driven by external physical forcings including surface wind stress and heat flux (Chen, Beardsley, \& Cowles, 2006). The unstructured grid and terrain-following sigma vertical coordinate of the model allows for accurate representation of coastline morphology. The FVCOM includes a General Ecological Module (GEM), which allows for flexible representation of the lower food web (Ji, Davis, Chen, \& Beardsley, 2008). The FVCOM was applied to Lake Michigan using 20 sigma layers of uniform thickness, and an unstructured grid consisted of 5,795 nodes and 10,678 model cells, with cell side lengths of 0.6-2.6 km near the coast and $4.5-6.8 \mathrm{~km}$ near the centre of the lake (median $3.1 \mathrm{~km}$ ) (Rowe et al., 2015). Rowe et al. (2017) implemented GEM as a phosphorus-limited, nutrient-phytoplankton-zooplankton-detritus model that simulates lower food web biomass and productivity, and included a dreissenid mussel (benthic filter feeder) compartment. Phosphorus loads from 38 tributaries were included in FVCOM-GEM. The geographic scope of our GRP model was confined by the boundary of FVCOM's spatial grid, which included Lake Michigan and Green Bay, but not upstream tributaries or drowned river mouths (Figure 1) (Rowe et al., 2015, 2017). Model development and skill assessment was reported by Rowe et al. (2015, 2017). We conducted additional skill assessment of the biophysical model for Green Bay (Supporting Information, S3) and a nearshore-offshore transect near Muskegon, MI. Observed chlorophyll-a and zooplankton data came from De Stasio et al. (2014) and Reed (2017) for Green Bay. S. Pothoven (unpublished data) at National Oceanic and Atmospheric Administration (NOAA) Great Lakes Environmental Research Laboratory (GLERL), and Pothoven and Fahnenstiel (2013) provided data for Muskegon. Particulate organic carbon data were obtained from the Lake Michigan Mass Balance Project (Rossmann, 2006). We used output data from 2010 from the Lake Michigan biophysical model to develop our baseline model scenario for all simulations and analyses (Rowe et al., 2015, 2017). For each simulation, we extracted biophysical model data from the day at the middle of each month unless otherwise noted.

\section{3 | Model sensitivity}

\subsection{1 | Phytoplankton carbon content and foraging duration}

We evaluated the model's sensitivity to varying assumptions with respect to phytoplankton carbon content and foraging duration. We selected two wet phytoplankton biomass:carbon $\left(C_{\text {Phy }}\right)$ ratios (20, 36) from the literature (Bowie et al., 1985; Fahnenstiel, Chandler, Carrick, \& Scavia, 1989; Peters \& Downing, 1984; Rowe et al., 2017) and two foraging durations ( $t=12$ or $t=24 \mathrm{hr}$ ). Foraging duration values were based on recorded observations of carp feeding rhythms (Dong \& Li, 1994; Wang, Flickinger, Be, Liu, \& Xu, 1989) and on previous BHC GRP models (Anderson et al., 2015, 2017; Cooke \& Hill, 2010). We considered scenarios for each combination of assumed carbon content and foraging duration. For each combination of assumptions, we determined the amount of prey required for $\mathrm{BHC}$ to maintain weight at temperatures typical of Lake Michigan $\left(2-26^{\circ} \mathrm{C}\right.$.

\subsection{2 | Feeding scenarios}

We ran the GRP model under six scenarios, characterised by the type(s) of prey and the volume of the water in which BHC can feed (surface layer or throughout the whole water column) to determine how these considerations affected the quality and quantity of suitable habitat. We defined suitable habitat as any cell that could support a non-negative growth (GRP $\geq 0 \mathrm{~g} \mathrm{~g}^{-1} \mathrm{day}^{-1}$, i.e. at a minimum, the carp maintains its weight), whereas habitat quality refers to the GRP value estimated for a given grid cell (higher GRP = higher habitat quality). For both surface and whole water column scenarios, we ran simulations under three different diets: (1) phytoplankton only; (2) phytoplankton and zooplankton; and (3) phytoplankton, zooplankton, and detritus. We used prey energy density values of $2,600 \mathrm{~J} / \mathrm{g}$ wet mass, 2,512 J/g wet mass, and $127.3 \mathrm{~J} / \mathrm{g}$ wet mass for phytoplankton, zooplankton, and detritus, respectively (Anderson et al., 2015, 2016, 2017). We attributed the energy density of dreissenid mussel biodeposits to all Lake Michigan detritus-assuming that this is the most prevalent detrital food source in the lake (Madenjian, 1995). Anderson et al. (2016) reported the caloric quality of biodeposits $\left(E D_{D e t}\right)$ as $979 \mathrm{~J} / \mathrm{g}$. However, the poor nutritional and energetic quality of organic detritus often reduces the amount of energy a fish can assimilate, i.e. energy content of a food item that can be used for metabolism or growth (Bowen, Lutz, \& Ahlgren, 1995). We accounted for this by adjusting $E D_{\text {Det }}$ by an assimilation efficiency coefficient of 0.13 , which we derived by back-calculating the assimilated energy density from the growth of juvenile BHC at the given food rations reported by Anderson et al. (2016). For each feeding scenario, we identified all cells containing suitable habitat and then calculated the volume-weighted GRP average within all 
of those cells to determine the overall quality of suitable habitat. We determined the total volume and extent of suitable habitat for each species and scenario. Total extent was calculated as the sum of the surface areas of water columns containing at least one nonnegative GRP model cell (hereafter referred to as GRP maxima). These scenarios were run from April to November.

\section{4 | Model simulations and analyses}

\subsection{1 | Habitat suitability assessments}

We evaluated habitat suitability throughout the lake for all 12 months of the year, while also investigating vertical distributions of habitat quality at three sites along a nearshore-offshore gradient at Muskegon. These assessments were run assuming diets of phytoplankton, zooplankton, and detritus. For our lake-wide assessment, we determined the total extent, volume, and mean GRP of suitable habitat. Total extent was based on GRP maxima. To account for scale-related bias caused by averaging GRP across variable depths (Mason \& Brandt, 1996), we mapped seasonal averages of GRP at three discrete depth ranges: near surface (NS; 0-10 m); DCL (10-50 m); and the whole water column (WC Mean). Near surface is based on range of depths at which BHC typically occupy in the Illinois River (DeGrandchamp, Garvey, \& Colombo, 2008; Garvey et al., 2015) and the DCL depths are defined by the range of recent observations of DCLs in Lake Michigan (Bramburger \& Reavie, 2016). For our vertical assessments, we focused on three sites along a nearshore-offshore transect near Muskegon (nearshore [M15]: $15 \mathrm{~m}$ depth; intermediate depth [M45]: $45 \mathrm{~m}$ depth, offshore [M110]: $110 \mathrm{~m}$ depth, Figure 1), that NOAA GLERL has sampled monthly since the mid-1990s (Pothoven \& Fahnenstiel, 2013). Muskegon simulations were run on a daily time step and analyses focused on characterising seasonal patterns, nearshoreoffshore differences, and vertical distributions of habitat quality from April to November.

\section{3 | RESULTS}

\section{1 | Comparison of FVCOM-GEM outputs to observations in Green Bay and Muskegon}

Biophysical outputs reflected the spatial and temporal patterns of temperature and prey in Green Bay and Muskegon. FVCOMGEM simulated higher prey concentrations in Green Bay in comparison to the main lake as well as the characteristic trophic gradient within the lower bay that stems from the mouth of the Fox River (De Stasio et al., 2014) (Figures S3.2-S3.4). The distribution of simulated prey concentrations at Muskegon reflected the nearshore-offshore gradient and plankton phenology with high prey concentrations in May and June in the nearshore and the formation of the deep chlorophyll maxima (DCM) in the offshore during late stratification (Figure 2; Table 1).

The range of prey values simulated by the model tended to underestimate chlorophyll and overestimate zooplankton in Green Bay (Table S3.1) and nearshore Muskegon (Figure 2; Table 1). At Muskegon, simulated planktonic prey biomass (phytoplankton + zooplankton; J/L) typically showed better agreement with observed data than when compared to each prey type individually (range of monthly means [March-December] at nearshore Muskegon: simulated $=2.0-10.02 \mathrm{~J} / \mathrm{L}$, observed = 2.7-12.5 J/L; Figure 2). In offshore Muskegon during June-October, the model reasonably simulated the range of planktonic prey biomass throughout the water column. The simulated DCM in late stratification (August-September) underestimated values reported by Pothoven and Fahnenstiel (2013) by about $1 \mu \mathrm{g} / \mathrm{L}$ and simulated temperature at the Muskegon DCM was approximately $2 \times$ greater than average temperature of Lake Michigan's DCLs (Table 1). Running our GRP model with observed total plankton biomass and temperatures at the offshore DCM near Muskegon indicated that bighead carp could still maintain minimal growth, but GRP was $34 \%$ of what was
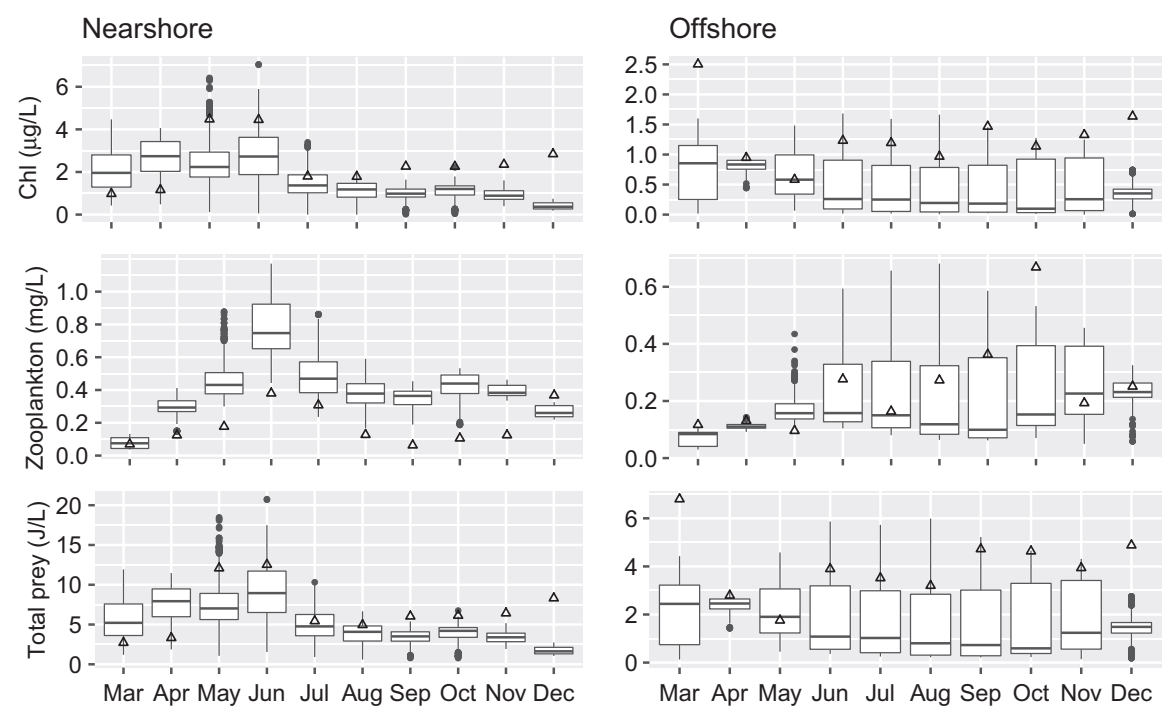

Mar Apr May Jun Jul Aug Sep Oct Nov Dec
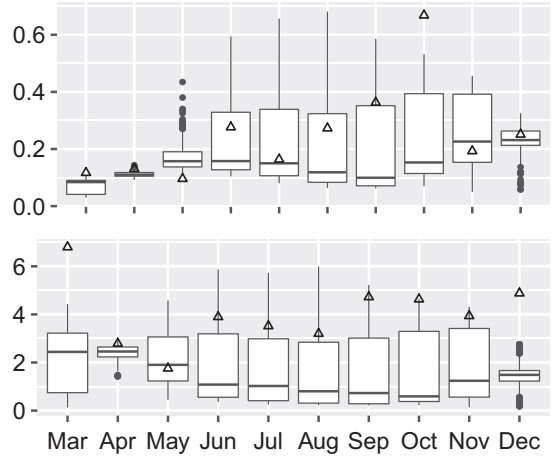

FIGURE 2 Simulated (box plots) and observed (triangles; Pothoven, unpublished data) mean chlorophyll concentration (Chl), zooplankton biomass, and total planktonic prey (phytoplankton and zooplankton) biomass in the water column at nearshore and offshore Muskegon in 2010 from March to December. Boxplot whiskers are $1.5 \times$ interquartile range 
TA B LE 1 Habitat conditions and model-predicted growth rate potential (GRP) in environments where bighead carp Hypophthalmichthys nobilis (BC) and silver carp Hypophthalmichthys molitrix (SC) exist compared to those observed and simulated in Lake Michigan. Growth rate potential values are based on diets of phytoplankton and zooplankton at the reported temperatures. Observed zooplankton in lower Green Bay represents the average of the two southern most sites (Benderville and Shoemaker Point) reported by Reed (2017). Data sources are indicated by superscripts (a, b, c, d). Superscripts next to the location indicate sources that provide data on three or more variables for that location

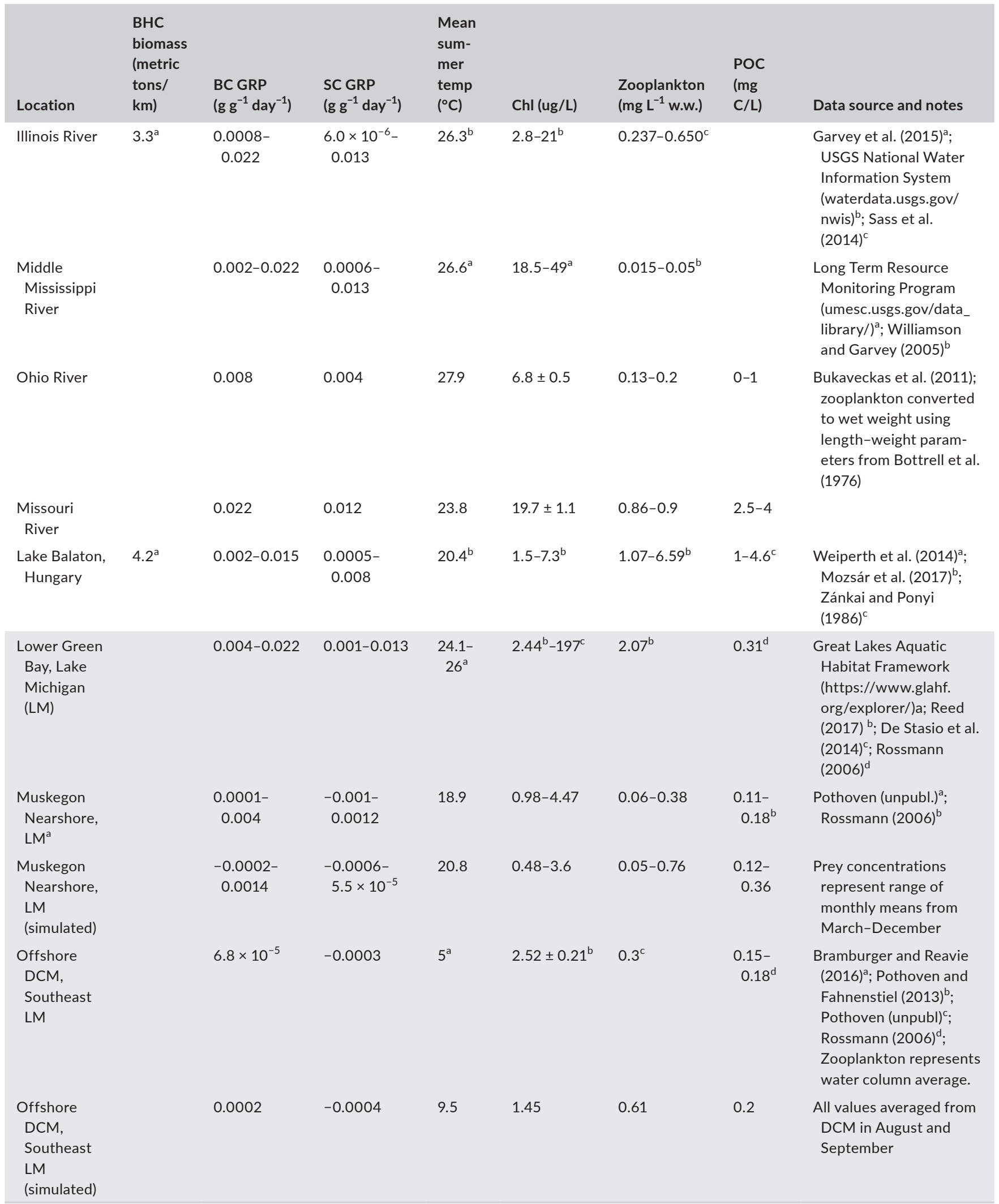

Abbreviations: BHC, bigheaded carp; Chl, Chlorophyll-a; POC, particulate organic carbon. 


\begin{tabular}{|lllll} 
Filtration hours & $\begin{array}{l}\text { Energetic require- } \\
\text { ment }(\mathrm{J} / \mathrm{L})\end{array}$ & $\mathrm{Chl}(\mu \mathrm{g} / \mathrm{L})$ & & Zooplankton $(\mathrm{mg} / \mathrm{L})$ \\
\hline Bighead carp & & $\mathrm{C}_{\mathrm{Phy}}=20$ & $\mathrm{C}_{\mathrm{Phy}}=36$ & \\
\hline 12 & $4.62-17.8$ & $3.2-12.3$ & $1.8-6.8$ & $1.84-7.08$ \\
\hline 24 & $2.31-8.9$ & $1.6-6.2$ & $0.9-3.4$ & $0.92-3.54$ \\
\hline Silver carp & & & & \\
\hline 12 & $13.69-43.24$ & $9.5-29.9$ & $5.3-16.6$ & $5.45-17.21$ \\
\hline 24 & $6.85-21.62$ & $4.7-15.0$ & $2.6-8.3$ & $2.72-8.61$ \\
\hline
\end{tabular}

TABLE 2 Prey concentrations and energy density required for a $5,480 \mathrm{~g}$ bighead carp Hypophthalmichthys nobilis and a 4,350 g silver carp Hypophthalmichthys molitrix to maintain weight in Lake Michigan's thermal regime for different combinations of filtration hours $(t)$ and wet phytoplankton biomass:carbon ratios $\left(C_{\mathrm{Phy}}\right)$

FIGURE 3 Average of bighead carp Hypophthalmichthys nobilis (a, b, e, f) and silver carp Hypophthalmichthys molitrix (c, d, g, h) growth rate potential (GRP, $\mathrm{g} \mathrm{g}^{-1} \mathrm{day}^{-1}$ ) in Lake Michigan from March to December for different combinations of filtration hours $(t)$ and wet phytoplankton biomass:carbon ratios $\left(C_{\text {Phy }}\right)$. Suitable habitats were defined by GRP maxima $\geq 0 \mathrm{~g} \mathrm{~g}^{-1}$ day $^{-1}$ for each water column. Grey areas indicate unsuitable habitat (GRP $<0 \mathrm{~g} \mathrm{~g}^{-1}$ day $^{-1}$ ) [Colour figure can be viewed at wileyonlinelibrary.com]
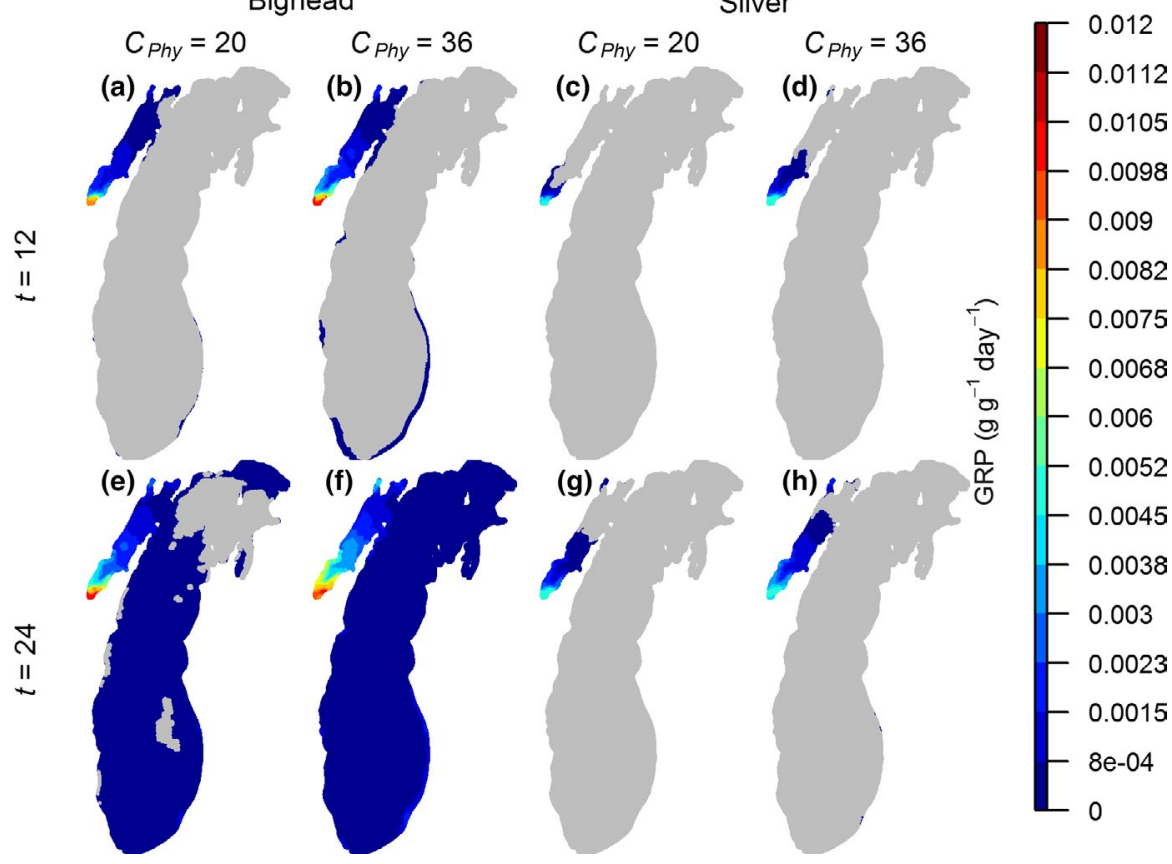

predicted by the model when it was run with simulated data. In Green Bay, reported prey biomass far exceeds the energetic inputs required by each species to maintain weight (Figures S3.4 and S3.5; Table 2). Thus, biases in the biophysical model outputs had a minor effect on the GRP model's determination of habitat suitability in Green Bay or Muskegon.

\subsection{Model sensitivity to phytoplankton carbon content and foraging hours}

The assumptions we used for our model indicated that bighead carp require 0.9-3.4 $\mu \mathrm{g} / \mathrm{L}$ of chlorophyll and silver carp require 3.3-8.3 $\mu \mathrm{g} / \mathrm{L}$ of chlorophyll to maintain weight at Lake Michigan temperatures (Table 2). Increases in temperature resulted in higher respiration rates, which increased the total amount of prey (g/day) required for weight maintenance. However, consumption rates were also positively influenced by temperature, which decreased the concentration of prey $(\mathrm{g} / \mathrm{L})$ required to maintain weight. The difference between $12-$ and $24-$ hr filtration had a greater effect on the extent and volume of suitable habitat for both species than did differences in phytoplankton carbon content. However, bighead carp was more sensitive to changes to either parameter than was silver carp (Figure 3). Additionally, adjusting both parameters resulted in offshore habitat becoming available for bighead carp, but silver carp habitat largely remained in Green Bay.

\section{3 | Feeding scenarios}

The average extent and volume of suitable bighead and silver carp habitat from April to November increased with the number of diet items for both surface and water column scenarios (Table 3 , Figure 4). The extent of suitable habitat for fish feeding throughout the water column was 1.0-1.9x greater than when the same fish fed on the same diet items at the surface. The difference in suitable habitat extent between water column and surface scenarios decreased as diet items increased. When feeding throughout the water column, the broadest diet (phytoplankton, zooplankton, and detritus) produced suitable habitat volumes $4.6 \times$ and $2.3 \times$ greater than the narrowest diet (phytoplankton only) for bighead and silver carp, respectively. The least restrictive scenario, which was when the fish fed on all three prey types throughout the water column, increased the extent of suitable habitat by $4 \times$ for bighead carp and $2.1 \times$ for silver carp compared to the most restrictive scenario where the fish fed only on phytoplankton at the surface. 
TAB LE 3 Area, volume, and mean growth rate potential (GRP) of suitable habitat for bighead carp Hypophthalmichthys nobilis and silver carp Hypophthalmichthys molitrix under different feeding scenarios averaged from April to November

\begin{tabular}{|c|c|c|c|c|c|c|c|}
\hline Species & Diet & \multicolumn{2}{|c|}{ Suitable area $\left(\mathrm{km}^{2}\right)$} & \multicolumn{2}{|c|}{ Suitable volume $\left(\mathrm{km}^{3}\right)$} & \multicolumn{2}{|c|}{ Mean GRP $\left(\mathrm{g} \mathrm{g}^{-1} \mathrm{day}^{-1}\right)$} \\
\hline \multirow[t]{3}{*}{ Bighead } & PP & $11,143.50$ & $21,205.88$ & 11.14 & 248.87 & 0.0009 & 0.0004 \\
\hline & PP_ZP & $31,224.03$ & $37,373.66$ & 31.22 & 769.37 & 0.0008 & 0.0004 \\
\hline & PP_ZP_Det & $43,308.28$ & $44,548.71$ & 43.31 & $1,144.91$ & 0.0008 & 0.0005 \\
\hline \multirow[t]{2}{*}{ Silver } & PP & $1,435.93$ & $1,584.67$ & 1.44 & 12.41 & 0.0016 & 0.0011 \\
\hline & PP_ZP_Det & $2,757.90$ & $3,043.10$ & 2.76 & 28.82 & 0.0014 & 0.0010 \\
\hline
\end{tabular}

Abbreviations: PP, phytoplankton only; PP_ZP, phytoplankton and zooplankton; PP_ZP_Det, phytoplankton, zooplankton, and detritus.

\begin{tabular}{|c|c|c|c|c|c|}
\hline \multicolumn{3}{|c|}{ Bighead } & \multicolumn{3}{c|}{ Silver } \\
\hline PP & PP_ZP & PP_ZP_Det & PP & PP_ZP & PP_ZP_Det \\
\hline
\end{tabular}
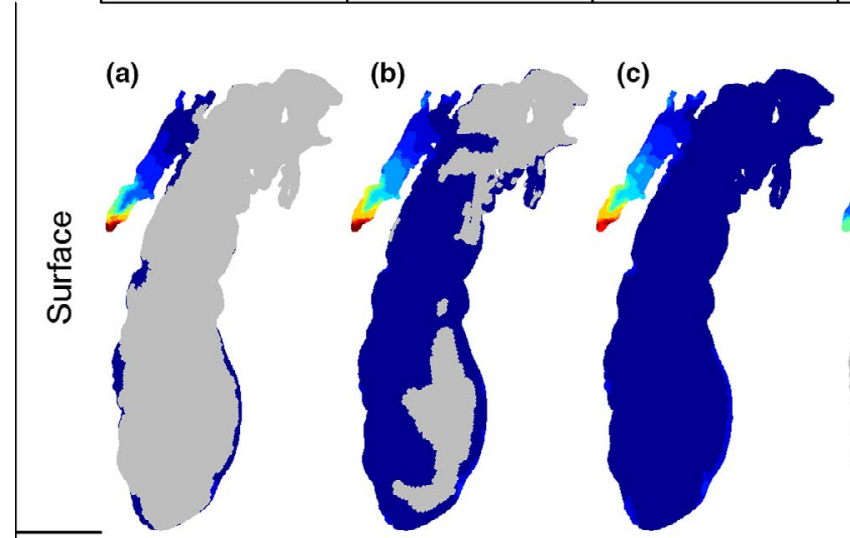

(d)
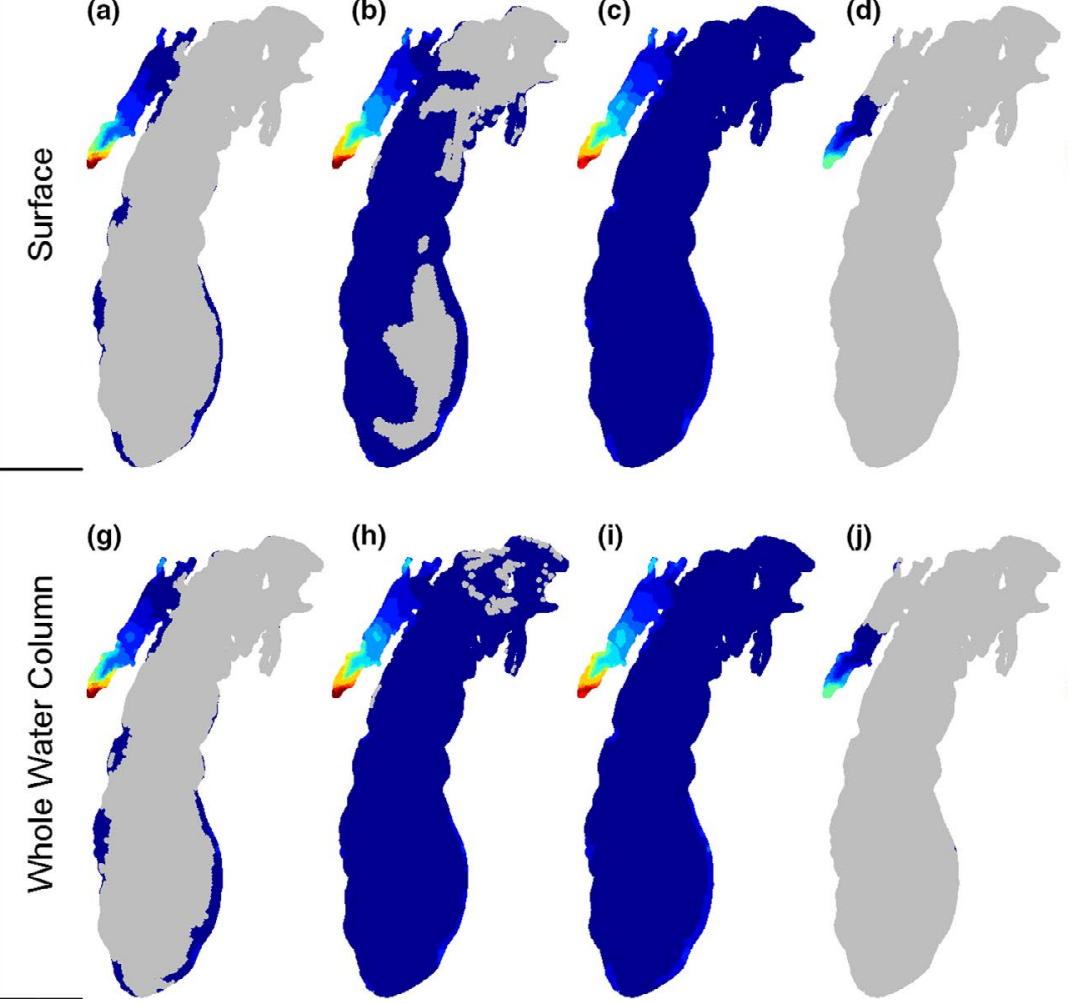

(h)

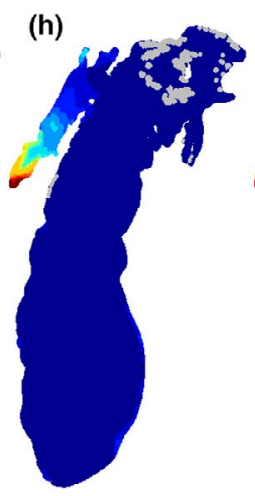

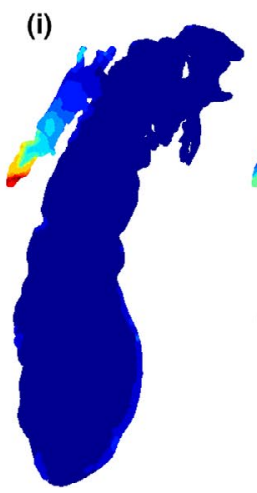

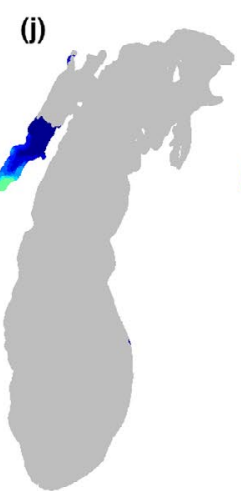

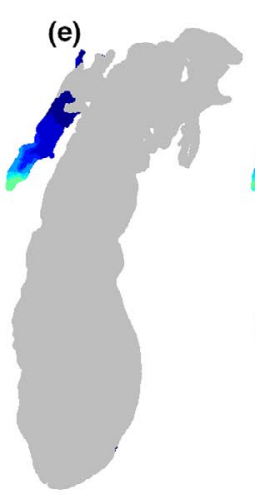

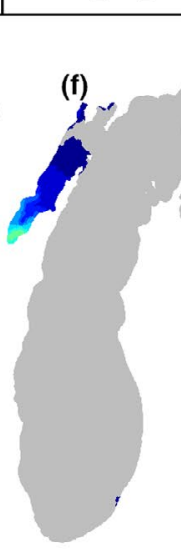

0.013
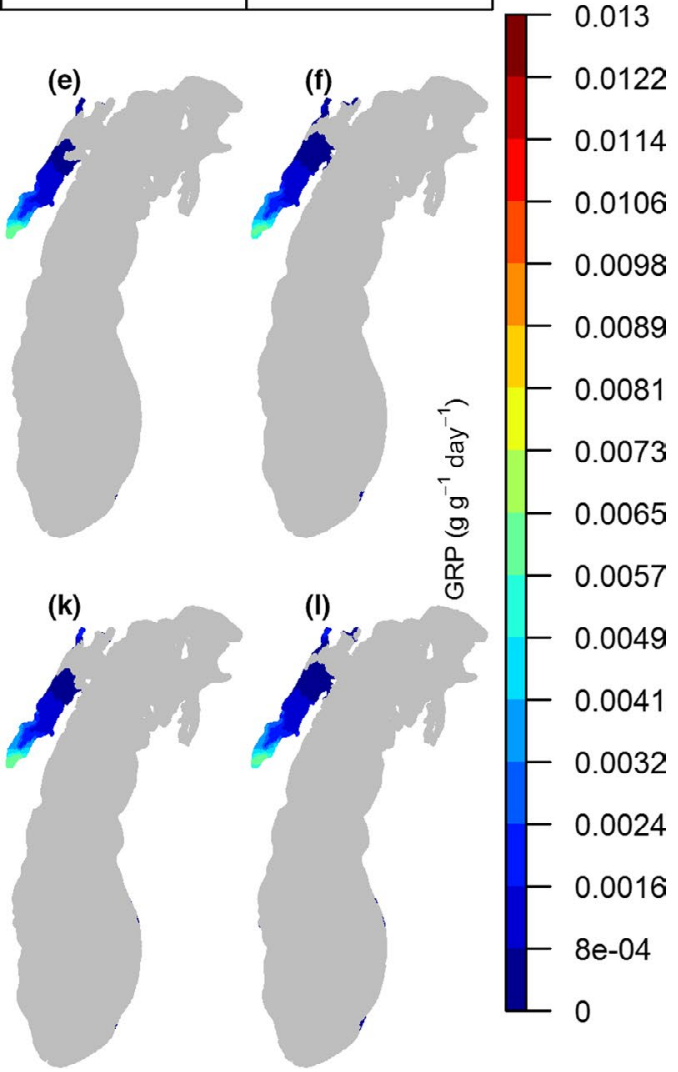

FIG URE 4 Average of bighead carp Hypophthalmichthys nobilis (a-c, g-i) and silver carp Hypophthalmichthys molitrix (d-f, j-I) growth rate potential (GRP) from April to November in Lake Michigan under different feeding scenarios. Suitable habitats were defined by GRP maxima $\geq 0 \mathrm{~g} \mathrm{~g}^{-1} \mathrm{day}^{-1}$ for each water column. Grey areas indicate unsuitable habitat (GRP $<0 \mathrm{~g} \mathrm{~g}^{-1}$ day $^{-1}$ ). PP, phytoplankton only; PP_ZP, phytoplankton and zooplankton; PP_ZP_Det, phytoplankton, zooplankton, and detritus [Colour figure can be viewed at wileyonlinelibrary. com]

\subsection{Habitat suitability assessments}

The extent (as indicated by total surface area), total volume, and quality of suitable habitat for $\mathrm{BHC}$ varied throughout the year (Figure 5). Bighead carp habitat was available from March to December, with the greatest volume attained in November $\left(1,734 \mathrm{~km}^{3}, 35 \%\right.$ of the total volume) and the greatest extent in September and October $\left(57,630 \mathrm{~km}^{2}, 100 \%\right.$ of the biophysical model's total surface area). Silver carp habitat was available from March to November, with the total volume and extent of suitable habitat peaking in August 
(a)

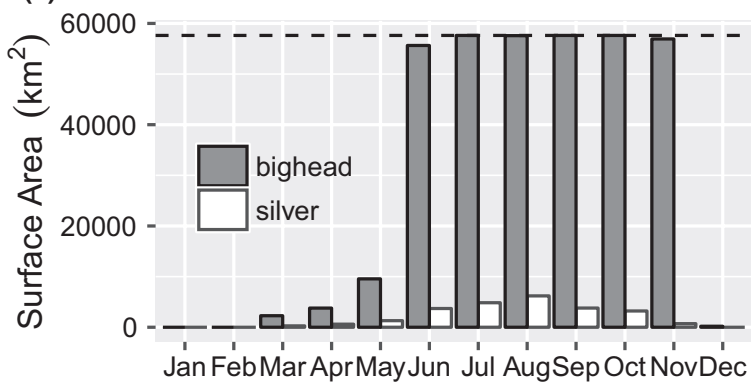

(b)

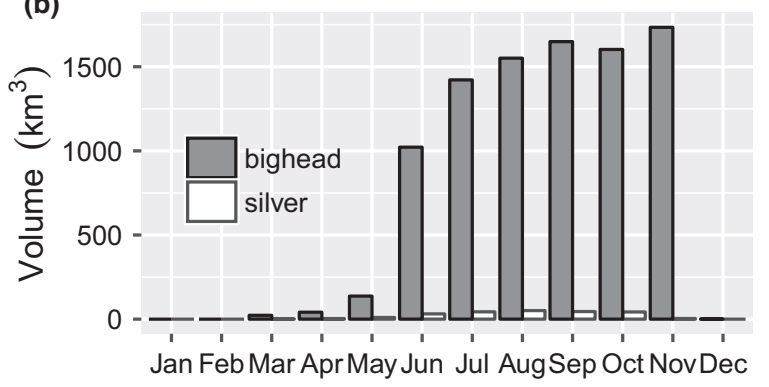

(c)

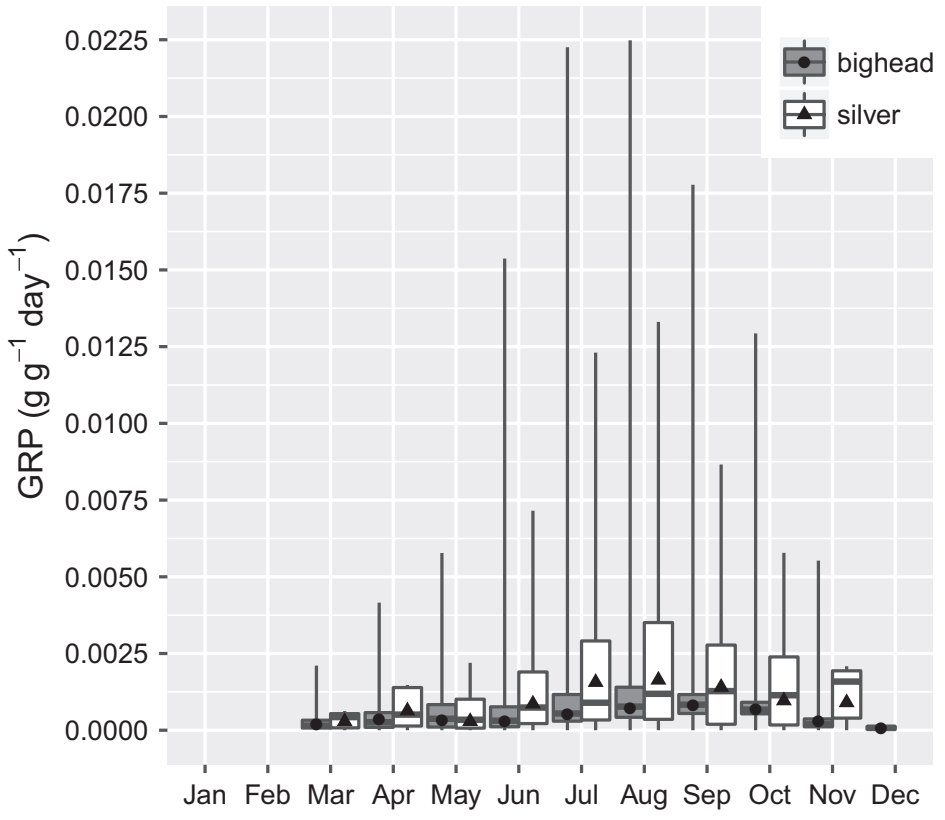

FIGURE 5 Total surface area (top left), volume (bottom left), and monthly growth rate potential (GRP) of suitable habitat for bighead carp Hypophthalmichthys nobilis and silver carp Hypophthalmichthys molitrix (GRP $\geq 0.0 \mathrm{~g} \mathrm{~g}^{-1} \mathrm{day}^{-1}$ ) from January to December. Dotted line in top left plot is the maximum surface area of the biophysical model's grid. Mean GRP is indicated by the filled circles (bighead) and triangles (silver) in each month's boxplot. Boxplot whiskers represent the minimum and maximum GRP values for each species and month

$\left(51 \mathrm{~km}^{3}\right.$ and $1 \%$ of the total volume, $6,193 \mathrm{~km}^{2}$ and $11 \%$ of total surface area). The highest average quality of suitable habitat was in September for bighead carp $\left(0.0008 \mathrm{~g} \mathrm{~g}^{-1} \mathrm{day}^{-1}\right)$ and in August for silver carp $\left(0.00164 \mathrm{~g} \mathrm{~g}^{-1}\right.$ day $\left.^{-1}\right)$.

The spatial distribution of suitable habitat differed between species and varied throughout the year. During the spring, silver carp habitat was predominantly concentrated in southern Green Bay and supported average growth rates of $0.0003-0.0006 \mathrm{~g} \mathrm{~g}^{-1} \mathrm{day}^{-1}$ (Figures 5, 6 and S4.1). Suitable habitat became available near Chicago, Milwaukee, and several river mouths along the south-eastern lakeshore (e.g. St Joseph, Kalamazoo, and Muskegon Rivers) in May and the subsequent summer months (June-August; Figure S4.1). During the summer, silver carp habitat covered a majority of Green Bay and expanded along the Indiana, Illinois, and Michigan shorelines. Several areas along the western shore influenced by tributary loads (e.g. Milwaukee, mouth of Root River, and Two Rivers, WI) also provided suitable habitat. Silver carp habitat receded back into the southern portion of Green Bay as autumn (SeptemberNovember) progressed. By December, all suitable silver carp habitat had disappeared. Averaging across the different depth ranges did not significantly affect extent of silver carp habitat for any season with exception to the DCL depth range since most of the suitable habitat was in shallow Green Bay and nearshore areas <10 m deep (Figure 6; NS, DCL, WC Mean).

Bighead carp habitat was more extensive than silver carp habitat throughout the year. Habitat along most of the southern shoreline and in Green Bay was capable of supporting bighead carp growth (0.0002$0.0004 \mathrm{~g} \mathrm{~g}^{-1} \mathrm{day}^{-1}$ ) in the spring (Figures 5, 7 and S4.2). From June to
November, most of the lake contained at least some suitable habitat in the water column (Figure S4.2). The southern portion of Green Bay, near the mouth of the Fox River, contained the best habitat quality throughout the year and was the only location capable of supporting growth in December (mean GRP $=8.0 \times 10^{-5} \mathrm{~g} \mathrm{~g}^{-1} \mathrm{day}^{-1}$ ). Suitable habitat deepened from spring to autumn (Figure 7). There were no obvious differences among the extent of suitable habitat for each depth range in the spring. In summer, however, average GRP in the NS produced a greater extent of suitable habitat than when GRP was averaged across the $\mathrm{DCL}$ depth range or the whole water column. The amount of suitable habitat across the DCL depth range increased substantially in the summer and autumn relative to the spring, but the quality of suitable habitat at these depths was relatively poor throughout the year.

\subsection{1 | Vertical distribution of habitat quality near Muskegon}

Average prey concentrations and temperatures exhibited vertical, nearshore-offshore, and seasonal patterns at Muskegon. Mean prey concentrations and water temperatures were greater in the nearshore (M15) and expressed more seasonal variability $\left(8.5 \pm 3.5 \mathrm{~J} / \mathrm{L} ; 13.6 \pm 5.1^{\circ} \mathrm{C}\right)$ than did prey and temperatures in the intermediate (M45: $5.9 \pm 1.2 \mathrm{~J} / \mathrm{L} ; 11.5 \pm 4.0^{\circ} \mathrm{C}$ ) and offshore (M110: $3.7 \pm 0.3 \mathrm{~J} / \mathrm{L} ; 7.5 \pm 2.4^{\circ} \mathrm{C}$ ) locations throughout the model run. Nearshore-offshore gradients in average prey concentration and temperature were more apparent in spring than in summer or autumn. June yielded the highest average prey concentrations in the nearshore and intermediate depth locations. Average prey 
FIGURE 6 Seasonal distribution of suitable silver carp Hypophthalmichthys molitrix habitat as represented by average growth rate potential (GRP) in the near surface waters (NS: 0-10 m), deep chlorophyll layer (DCL; 10-50 m), whole water column (WC Mean), and GRP maxima observed throughout the water column (WC Max). Spring: MarchMay; Summer: June-August; Autumn: September-November [Colour figure can be viewed at wileyonlinelibrary.com]

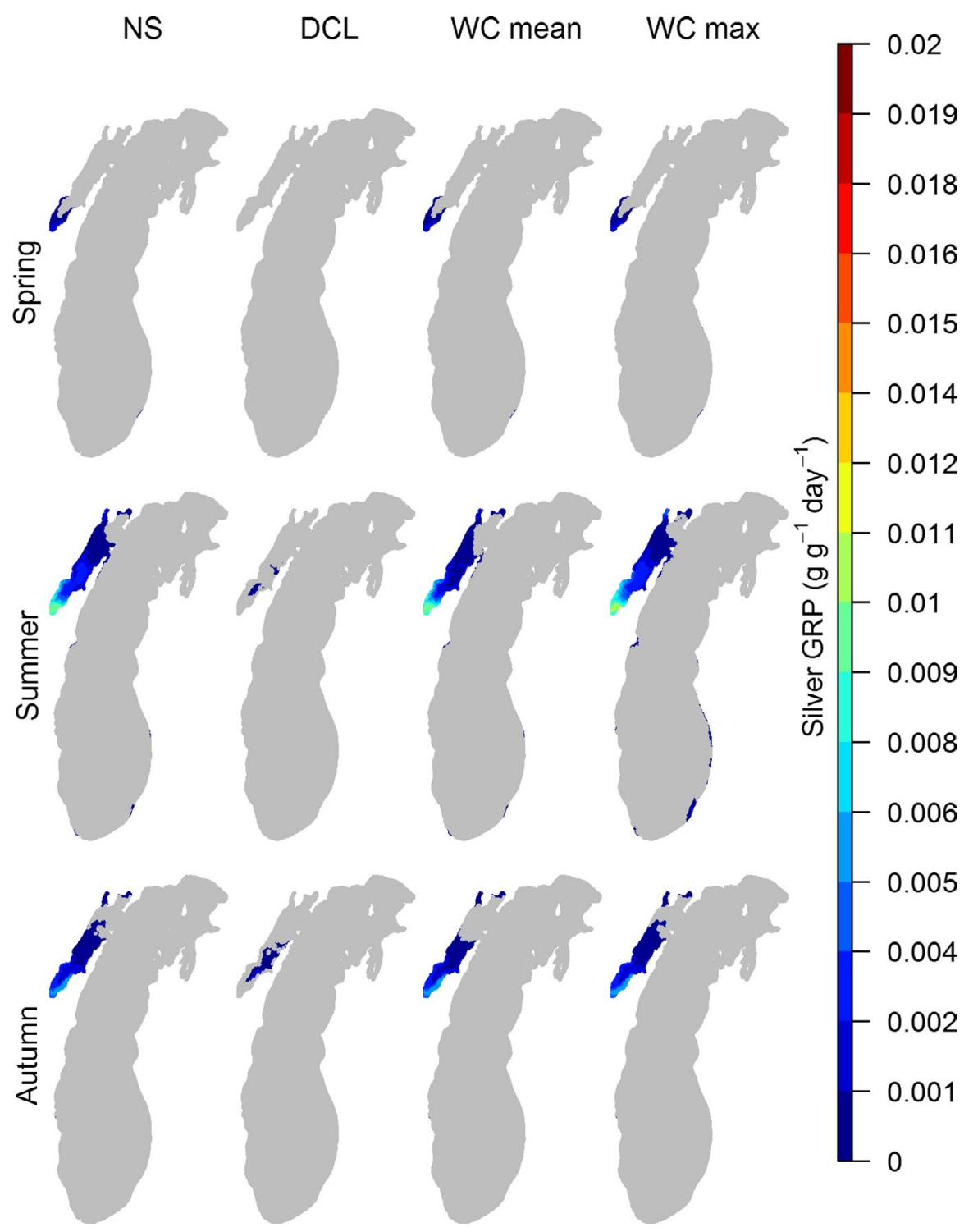

concentrations in the offshore were greatest in November but overall exhibited little seasonal variability (April-November mean and standard deviation: $3.7 \pm 0.3 \mathrm{~J} / \mathrm{L}$ ). Summer months (June-August) exhibited the most variability in the vertical distribution of prey and temperature for all depth locations. Vertical distributions of prey and temperature were evenly distributed throughout the water column during periods of mixing and unevenly distributed during periods of stratification (Figure 8). Prey concentrations were highest in the epilimnion in June for all locations but the offshore, which saw maximum prey concentrations around $25 \mathrm{~m}$. Prey concentration maxima were located beneath the surface from July to October.

Variations in prey concentrations and water temperature resulted in varied vertical, nearshore-offshore, and temporal distributions of habitat quality for BHC (Figures 8 and 9). Vertical distribution of habitat quality exhibited similar seasonal patterns at all depth locations. In April, GRP was ubiquitously distributed throughout the water column, but suitable habitat only existed for bighead carp in the nearshore (Figure 9). In June, GRP maxima were observed in the epilimnion across all locations; the nearshore epilimnion in June produced the greatest GRP at Muskegon for both species throughout the model run. Suitable silver carp habitat was present from late May to late September in the nearshore, only in June at the intermediate depth location, and never present in the offshore. In late summer, the highest quality habitat for both species within each transect was between 10 and $20 \mathrm{~m}$, although, at this time, suitable silver carp habitat was only present in the nearshore whereas the model simulated suitable bighead carp habitat in all three transects. For both species, there was a clear nearshore-offshore gradient as the nearshore retained the highest habitat quality throughout most of the year and dwarfed offshore GRP maxima by an order of magnitude (Figure 9).

\section{DISCUSSION}

\section{1 | Diet flexibility improves establishment potential}

In support of our hypothesis, the addition of zooplankton and detritus to model diets increased the amount of suitable habitat for 
NS

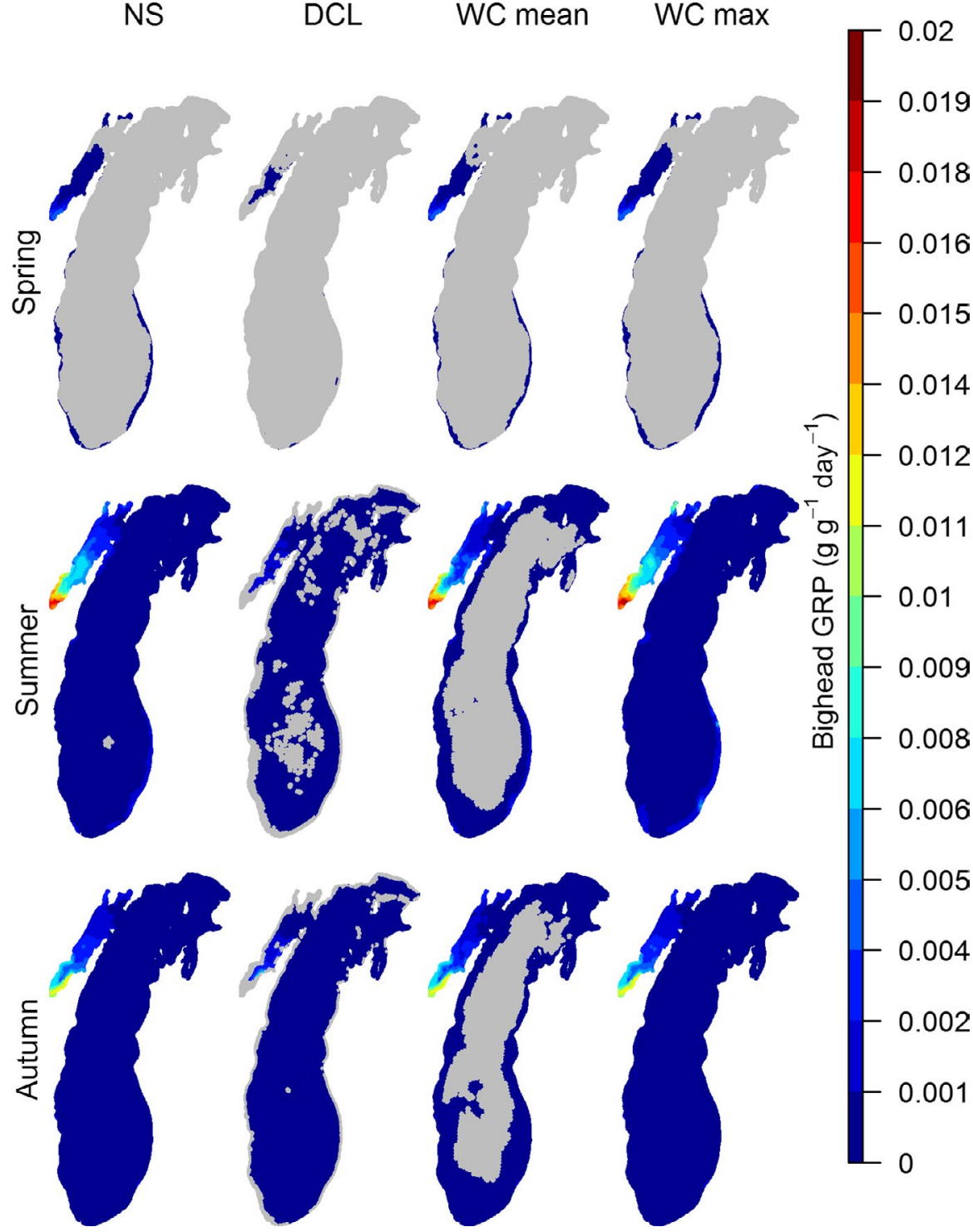

FIGURE 7 Seasonal distribution of suitable bighead carp Hypophthalmichthys nobilis habitat as represented by average growth rate potential (GRP) in the near surface waters (NS: 0-10 m), deep chlorophyll layer (DCL; 10-50 m), whole water column (WC Mean), and GRP maxima observed throughout the water column (WC Max). Spring: MarchMay; Summer: June-August; Autumn: September-November [Colour figure can be viewed at wileyonlinelibrary.com] both species and extended it into the offshore for bighead carp. Diet plasticity is a trait common to highly invasive fishes (Pettitt-Wade, Wellband, Heath, \& Fisk, 2015) including BHC, which feed opportunistically based on the relative abundance of different prey types in their immediate environment (Chen, 1982; Cooke et al., 2009; Kolar et al., 2007; Mozsár et al., 2017). Bigheaded carp feed heavily on zooplankton, detritus, bacteria, and algae in Lake Donghu, China (Chen, 1982), and they are thriving on diets dominated by inorganic matter and zooplankton in Lake Balaton, Hungary (Boros, Mozsár, Vitál, Nagy, \& Specziár, 2014; Mozsár et al., 2017). However, $\mathrm{BHC}$ do not exist in any ecosystems that are exactly comparable to Lake Michigan and there is a lack of information on how BHC have adapted to the cool, less productive lakes they do inhabit. In light of this, Lake Balaton may be the best available reference for predicting how BHC might adapt to Lake Michigan, as Lake Balaton is a dreissenid-invaded, meso-oligotrophic lake in a temperate climate with accessible information on the ecology of its established hybrid BHC (bighead $\times$ silver) population. While Lake Michigan is deeper, larger, and generally colder than Lake Balaton, our model suggests that the ability of BHC to flexibly feed on phytoplankton, zooplankton, and detritus mitigates their risk of starvation-even in offshore waters-and, therefore, increases their probability of establishment. Furthermore, Anderson et al. (2016) demonstrated that BHC mitigated their weight loss and, in some cases, even gained weight when feeding only on dreissenid biodeposits. This suggests that the beneficial effect of supplementing model diets with detritus simulated by our model was reasonable given that BHC would have access to additional prey resources and a greater abundance of biodeposits in Lake Michigan than the rations fed to them by Anderson et al. (2016).

Broadening the model diets of BHC increased the connectivity of suitable habitat, which has implications for their ability to spread throughout the lake. Bigheaded carp would have to travel through long stretches of plankton-depleted, open waters to reach productive areas in Lake Michigan. However, BHC are capable of swimming long distances and fasting for extended periods (DeGrandchamp et al., 2008; Sheng \& Ma, 2008). These traits, paired with our results, suggest that Lake Michigan's poor food conditions would not deter bighead carp from reaching more eutrophic areas if they feed opportunistically 


\section{Temperature $\left({ }^{\circ} \mathrm{C}\right)$}

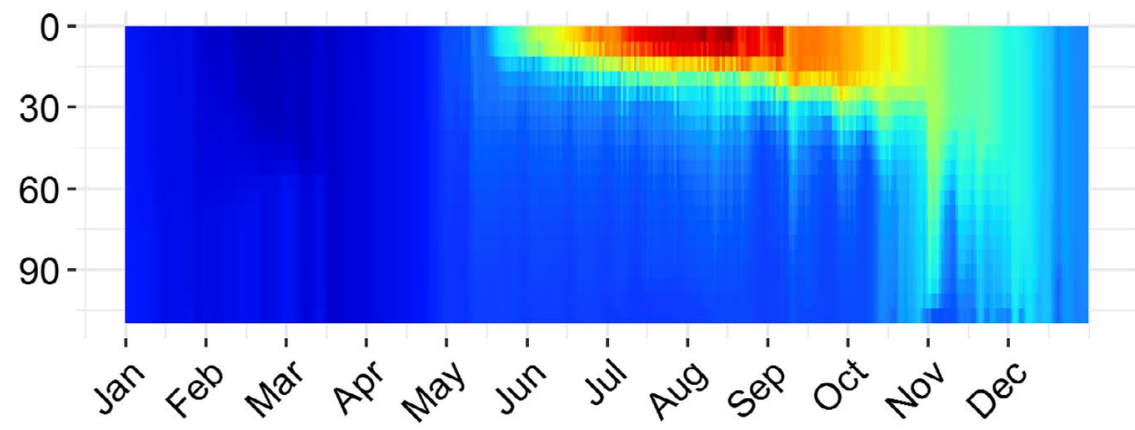

Prey $(\mathrm{J} / \mathrm{L})$

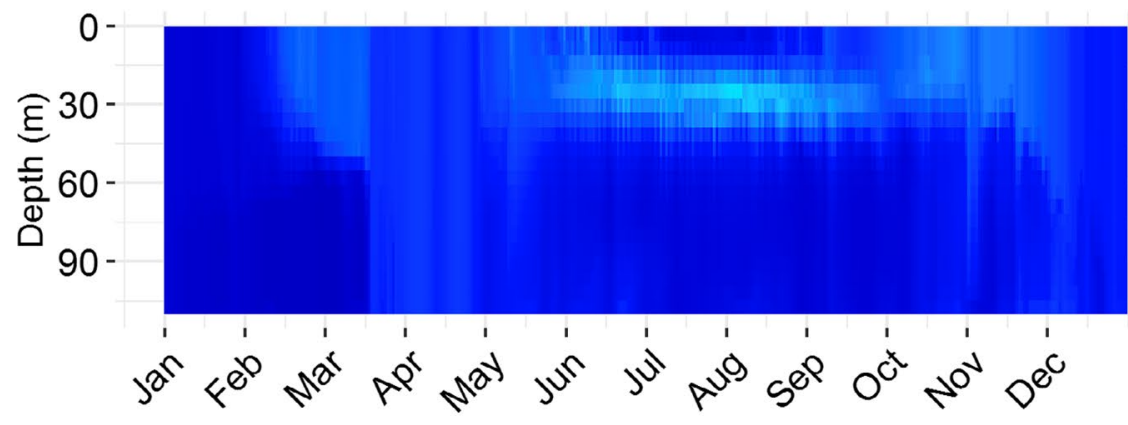

Bighead GRP $\left(\mathrm{g} \mathrm{g}^{-1}\right.$ day $\left.^{-1}\right)$

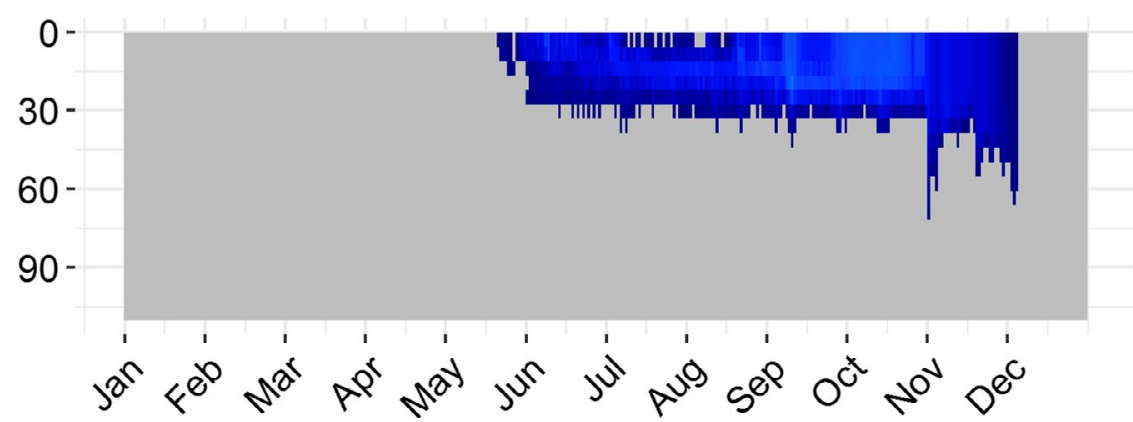

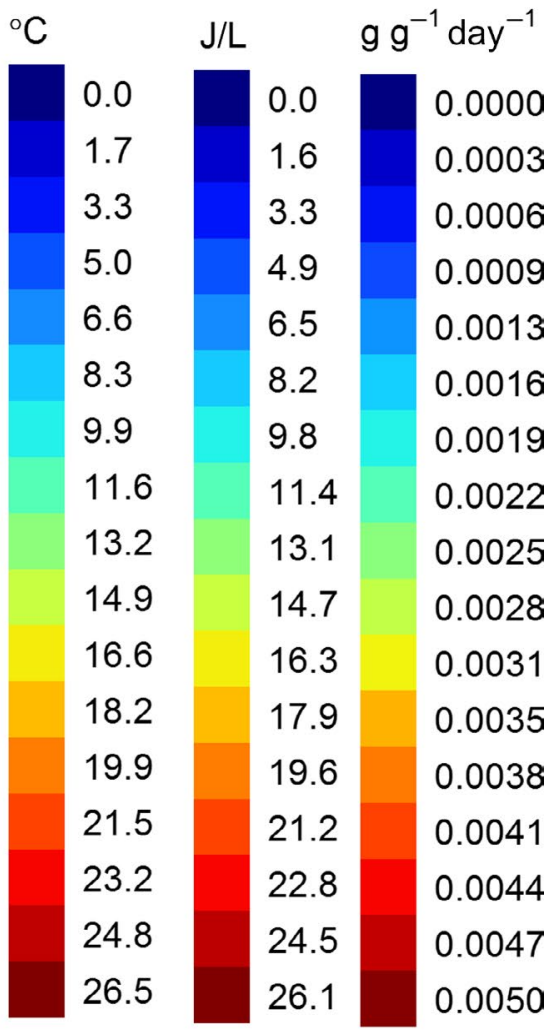

FIGURE 8 Vertical distribution of temperature (top), prey (middle), and bighead carp Hypophthalmichthys nobilis habitat quality (bottom) at the offshore depth location along a nearshore-offshore transect at Muskegon, MI (Figure 1; filled squares) throughout the year. Grey areas in the bottom panel indicate unsuitable habitat (growth rate potential [GRP] $<0.0 \mathrm{~g} \mathrm{~g}^{-1} \mathrm{day}^{-1}$ ) [Colour figure can be viewed at wileyonlinelibrary.com]

on detritus and plankton during their migration through less productive corridors. Using an area-restricted individual-based model, Currie, Cuddington, Stewart, Zhang, and Koops (2012) determined that BHC could reach Green Bay and other productive areas within the first year of escape from the Chicago Sanitary Shipping Canal and could find favourable habitat within a month. Therefore, it seems likely that $\mathrm{BHC}$ could survive, establish, and spread to favourable habitat in Lake Michigan and its tributaries despite having to travel across expansive areas with minimal plankton biomass.

\section{2 | Refuge beneath the surface}

Our findings indicate that subsurface temperatures and prey biomass are sufficient to support bighead carp growth and provide favourable habitat quality during late summer stratification. However, average chlorophyll concentrations $(2.52 \mu \mathrm{g} / \mathrm{L})$ at the offshore DCM during late stratification (August-September) are near the lower limit required for bighead carp to maintain weight at average $\mathrm{DCL}$ temperature $\left(5^{\circ} \mathrm{C}\right)$. This indicates that the suitability of this habitat is likely to be highly sensitive to variability in prey and temperature, which could affect how $\mathrm{BHC}$ would utilise the DCL.

It is uncertain how these fishes would use subsurface habitat and distribute themselves throughout Lake Michigan's water column. In the Illinois River, BHC typically occupy depths between 4 and $5 \mathrm{~m}$ and demonstrate seasonal habitat preferences (DeGrandchamp et al., 2008; Garvey et al., 2015). In Lake Michigan, however, peak prey biomass at the DCL and preferred temperatures are vertically separated 


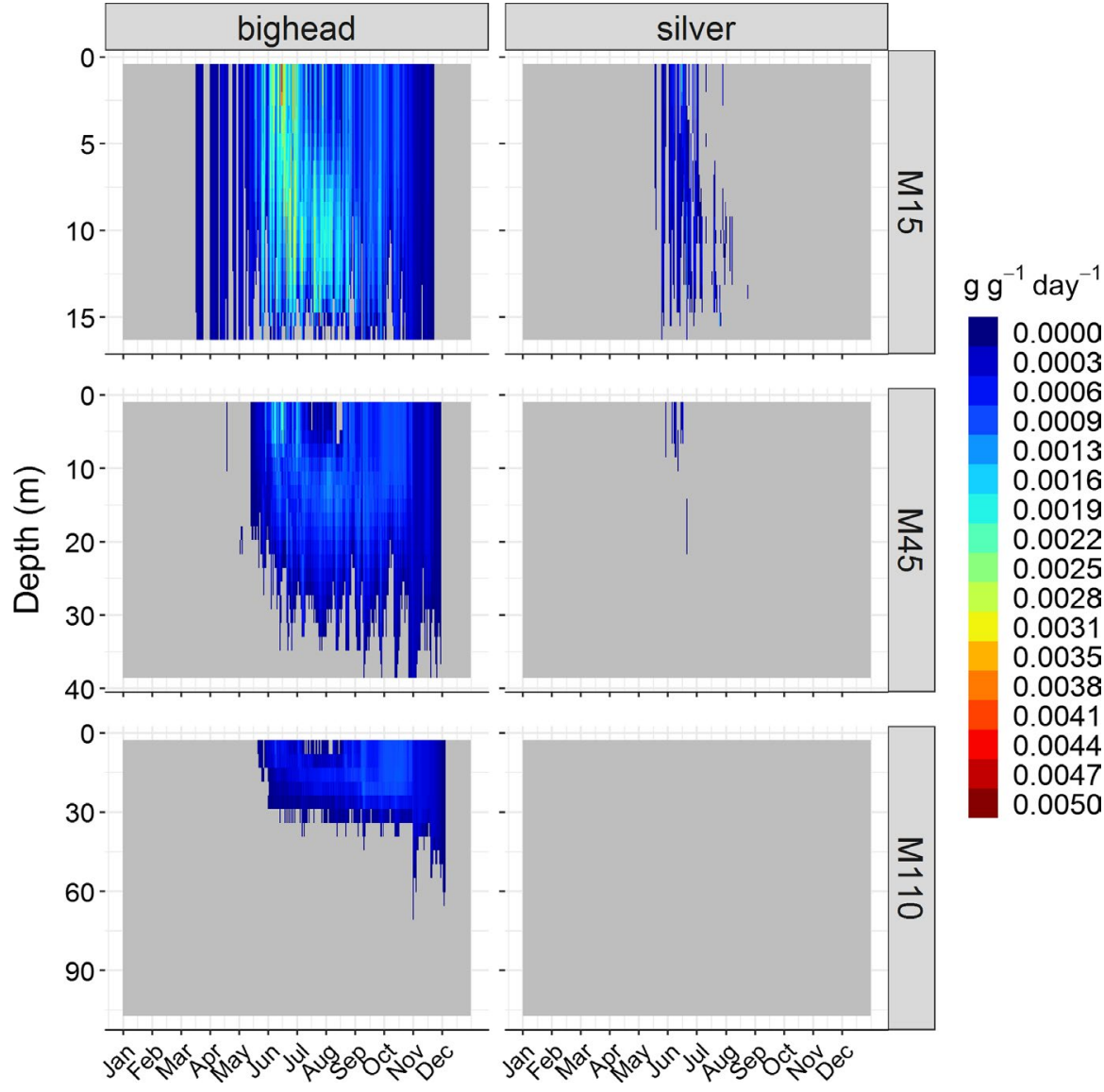

FIGURE 9 Vertical distribution of bighead Hypophthalmichthys nobilis and silver carp Hypophthalmichthys molitrix habitat quality at three depth locations along a nearshore-offshore transect at Muskegon, MI (Figure 1; filled squares) throughout the year. Grey areas indicate unsuitable habitat (growth rate potential [GRP] $<0.0 \mathrm{~g} \mathrm{~g}^{-1} \mathrm{day}^{-1}$ ). M15: nearshore depth location; M45: intermediate depth location; M110: offshore depth location [Colour figure can be viewed at wileyonlinelibrary.com] when the lake is stratified causing GRP to be differentially regulated by these two variables based on the fishes' position in the water column. While BHC exist in dimictic lakes (e.g. Lakes Dgal Wielki and Dgal Maly in Poland; see Napiórkowska-Krzebietke, Szostek, Szczepkowska, and Błocka, 2012), there is a lack of accessible information on how they behave in these systems. We assume $\mathrm{BHC}$ would migrate to warm and productive tributaries rather than reside in the main lake. However, if they were to reside in the lake, our results suggest that $\mathrm{BHC}$ might inhabit depths outside of their preferred thermal range to optimise growth during summer stratification. Furthermore, $\mathrm{BHC}$ might optimise their growth through behaviours that our model could not simulate. For instance, it is possible that BHC would feed at the cooler DCL but reside in warmer surface waters when they were not feeding. Bioenergetic optimisation has been used to explain depth distributions of fishes in thermally stratified lakes (e.g. Plumb, Blanchfield, and Abrahams (2014)), so it seems plausible that BHC would change their position in the water column to enhance their growth. However, our model did not account for energetic costs of movement, which could be an important consideration for evaluating the energetic trade-offs of foraging at the DCL. Identifying and translating literature published in non-English languages on $\mathrm{BHC}$ behaviour in dimictic lakes, as well as developing individual-based models that can simulate potential behaviours and movements (e.g. Currie et al., 2012), would be worthy research endeavours for understanding how $\mathrm{BHC}$ might adapt to the Great Lakes.

\section{3 | Interspecific differences}

The difference in habitat suitability between bighead carp and silver carp was one of the more counterintuitive findings from our research considering that these species share many ecological traits. Our model suggests that silver carp have greater prey requirements for growth than bighead carp and, therefore, the amount of suitable silver carp habitat is limited to the most productive areas of Lake Michigan. Our simulations agree with observed individual growth rates of bighead and silver carp existing in the same environments. $\mathrm{Ke}$, Xie, and Guo (2008) observed that bighead carp grew more quickly than silver carp in the hypereutrophic Lake Taihu in China, although the difference between the two species' growth rates was greatly reduced in years of high competition compared to years of low competition. Additionally, length-at-age data from the Middle Mississippi River suggests that bighead carp grow more quickly than silver carp, but silver carp maintain higher growth conditions (Weight/Length) in this system (Nuevo, Sheehan, \& Willis, 2004; Williamson \& Garvey, 2005). Thus, the interspecific differences we simulated are partially corroborated by reported growth rates, but further consideration is warranted of how certain model parameters could be affecting this.

The specific bighead and silver carp we used in our model had notably different energy densities, which might explain the difference in the amount of suitable habitat our model predicted for the two 
species. We used species-specific parameters for fish mass and energy density, which were averaged from 10 fish from the Mississippi and Missouri River drainages derived by Anderson et al. (2015). The silver carp used in that study were in excellent condition and the females had highly developed ovaries, whereas the bighead carp exhibited moderate to low condition, as is common for this species in parts of North America where they coexist with a dense population of silver carp (D.C. Chapman, U.S. Geological Survey, Columbia Environmental Research Center-personal communication). Coulter, MacNamara, Glover, and Garvey (2018) documented this negative relationship of $\mathrm{BHC}$ body condition and population density in the Illinois River, which demonstrates that fish at the invasion front are in higher condition due to less intraspecific and interspecific competition. Our model does not account for the effects of competition between the species on GRP, but realised growth rates would be affected by this and could have implications on which species is most likely to establish in Lake Michigan and whether coexistence is possible. Therefore, the interspecific differences our model simulated agree with observations from other ecosystems, but probably only represent a potential scenario of Lake Michigan's suitability for BHC given the condition of the fishes we assumed in our model and the absence of competition. We hypothesise that the amount of suitable habitat for silver carp would be similar to that predicted for bighead carp if we had assumed a similarly low energy density for both species. Furthermore, energy density was static in our simulations but in fishes this can fluctuate seasonally, ontogenetically, and in response to starvation (Breck, 2008; Hartman \& Brandt, 1995; Madenjian et al., 2006). Thus, the energy density of BHC could decrease in response to low food availability in certain areas of Lake Michigan, which in turn could affect their growth potential or habitat suitability in ways that our model could not capture.

\subsection{Oases in the desert: Tributary-affected nearshore areas and river mouths}

While our results show that the overall extent of high-quality habitat for $\mathrm{BHC}$ remains relatively small, we maintain that the risk of localised establishment events is still high near river mouths and other areas affected by tributary nutrient loads. Our model simulated suitable habitat near the mouths of several tributaries throughout the year, including the Milwaukee and St Joseph Rivers, which both possess sufficient water quality characteristics, temperatures, and hydraulics to support BHC spawning and egg development (Murphy $\&$ Jackson, 2013). The availability of productive feeding grounds and viable spawning habitat upstream suggests that carp may concentrate near river mouths, and thus improve their probability of establishing sustainable populations in light of low propagule pressure and population density (Cuddington et al., 2014; Jerde, Bampfylde, \& Lewis, 2009). Cuddington et al. (2014) found that a greater number of suitable spawning rivers reduced the chance of $\mathrm{BHC}$ finding mates given a small introduction event (i.e. 20 males, 20 females). This suggests that the limited availability of viable spawning rivers may actually facilitate BHC establishment rather than deter it.
Similarly, it seems that the limited number of productive habitats could further increase the probability of finding a mate. Bigheaded carp locate and selectively feed in areas of higher prey concentrations (Calkins, Tripp, \& Garvey, 2012; Currie et al., 2012; Dong \& Li, 1994), which, for spawning females, can lead to higher fecundities and potentially higher recruitment rates due to improved maternal condition (Degrandchamp, Garvey, \& Csoboth, 2007). Food requirements for BHC in their early life stages are probably less-due to their smaller size and energy densities-than that for the adult BHC we used in our study, which suggests productive river mouths that can support adult $\mathrm{BHC}$ growth would also provide sufficient food for the completion of larval and juvenile stages. Therefore, the benefits river mouths provide make these areas-and the variety of resident fish species that depend on them in their early life stages (Harris, Ruetz, Wieten, Altenritter, \& Smith, 2017; Janetski, Ruetz, Bhagat, \& Clapp, 2013)-particularly vulnerable to a BHC invasion.

\subsection{Model limitations and uncertainty}

We designed our feeding scenarios to assess the importance of diet flexibility in a way that would reflect realistic foraging behaviour and make our results comparable to Anderson et al. (2017) and (Cooke $\&$ Hill, 2010). Thus, the design of this analysis was to evaluate realistic conditions and scenarios comparable to previous work instead of using a factorial design that would evaluate the individual importance of each food type to habitat suitability.

The sensitivity of BHC GRP to assume phytoplankton carbon content and foraging duration in the model reinforce the importance of estimated prey consumption to overall model accuracy (Bartell, Breck, Gardner, \& Brenkert, 1986; Mason et al., 1995). Carbon composition of phytoplankton varies by species, cell size, physiological conditions, and environmental conditions (Bowie et al., 1985), and foraging duration can vary in accordance with day light hours, food availability, and water temperature (Dong \& Li, 1994; Li, Yang, \& Lu, 1980; Wang et al., 1989). Adjusting carbon content of prey and foraging duration significantly influenced estimated consumption rates and GRP in our model, which translated into substantially different estimates of suitable habitat. Furthermore, BHC can forage at spatial scales smaller than our model could effectively assess (range of grid cell surface areas $=0.2-29.5 \mathrm{~km}^{2}$, median $=7.2 \mathrm{~km}^{2}$ ). Growth rate potential model predictions are influenced by the spatial resolution of environmental data and the scale at which it is analysed (Mason \& Brandt, 1996), which indicates that higher resolution data would allow our model to better capture the patchiness in prey and the resulting extremes in GRP within a scale more similar to the foraging radius of $\mathrm{BHC}$.

Developing consumption parameters and a filtration equation for an adult BHC would improve the model's reliability. We used the same values for CA and CB as Anderson et al. (2015, 2017), which were derived from Wang et al. (1989). Anderson et al. (2015) state that these values produced more realistic simulations than the values Cooke and Hill (2010) derived from Smith (1989); 
however, both Wang et al. (1989) and Smith (1989) focused on analysing consumption patterns in juvenile $\mathrm{BHC}$ much smaller than those used in our simulations. Extrapolating relationships for filtration rate and consumption from juvenile fish to adult fish probably biases consumption and GRP. Thus, future research could improve on our model by researching, integrating, and validating the consumption parameters and filtration rate equation for larger BHC.

Our model assumed $100 \%$ filtration and retention efficiency for both species and, therefore, did not account for the effect of prey size on BHC consumption and GRP. Differences in gill morphology dictate the particle size that these fishes can efficiently filter, with bighead carp more efficient at removing larger particles and silver carp are more adept at filtering finer particulates (Dong \& Li, 1994). However, both species see significantly reduced efficiencies for particles near 8-10 $\mu \mathrm{m}$ (Cremer \& Smitherman, 1980; Smith, 1989). This is relevant considering that $>50 \%$ of Lake Michigan chlorophyll is comprised of pico- $(<2 \mu \mathrm{m})$ and nanoplankton $(2-20 \mu \mathrm{m})$ communities (Carrick et al., 2015; Cuhel \& Aguilar, 2013), which historically have included more single-celled organisms than the colonial organisms (Fahnenstiel \& Carrick, 1992) that would be more susceptible to $\mathrm{BHC}$ filtration. An exception to this might be in eutrophic areas like Green Bay (see De Stasio et al., 2014) where the size-selective grazing pressure of dreissenid mussels has promoted the dominance of colonial species (e.g. Microcystis) that are not effectively filtered by dreissenids but could be easily consumed by BHC. Additionally, FVCOM-GEM's zooplankton variable was calibrated to data reported by Vanderploeg et al. (2012) who used 153- $\mu \mathrm{m}$ vertical net tows, which cannot effectively capture microzooplankton such as rotifers that are common in the diets of BHC (Sampson et al., 2009; Williamson \& Garvey, 2005). Thomas, Chick, and Czesny (2017) found that microzooplankton made up $74 \%$ of mean total zooplankton biomass with rotifers comprising $51 \%$ alone, and that sampling with $64-\mu \mathrm{m}$ mesh nets underestimates total zooplankton biomass by nearly three-fold compared to methods that utilise finer mesh screens (i.e. 20- $\mu \mathrm{m}$ ). Therefore, incorporating microzooplankton biomass and particle size-based filtration and retention efficiencies into future GRP models should be a priority given the potential implications it could have on the establishment of $\mathrm{BHC}$.

\section{5 | CONCLUSION}

Our model predicted a greater extent of suitable habitat for BHC than did previous models; however, the best habitat was concentrated in nearshore areas and Green Bay, which is in agreement with the findings of Anderson et al. (2017) and Cooke and Hill (2010). Moreover, our results suggest that there may be cross-lake migration corridors that could facilitate establishment and spread. We were able to build on previous research and advance current understanding of establishment risk by running our bioenergetics model with simulated water quality variables from a Lake Michigan biophysical model (Rowe et al., 2017), which allowed us to demonstrate how diet plasticity and the availability of subsurface prey increases Lake Michigan's vulnerability to BHC establishment. Our findings provide further evidence of the invasion risk these species pose to the Great Lakes and can help managers prioritise surveillance efforts by identifying where in the lake BHC might spread upon introduction.

\section{ACKNOWLEDGMENTS}

The Michigan Sea Grant Graduate Research Fellowship funded this project (NA14OAR4170070) and the Michigan Department of Natural Resources-Institute for Fisheries Research provided matching funds. We would like to thank Michigan Sea Grant, Institute for Fisheries Research, the Cooperative Institute for Great Lakes Research (CIGLR), NOAA GLERL, and the Great Lakes Aquatic Non-indigenous Species Information System (GLANSIS) for providing additional support for this research. We would like to acknowledge the Great Lakes Aquatic Habitat Framework and GLANSIS for their efforts to share our maps with the public. We also would like to thank Steve Pothoven (NOAA GLERL) for providing chlorophyll and zooplankton measurements from Muskegon, MI. Funding was awarded to CIGLR through the NOAA Cooperative Agreement with the University of Michigan (NA17OAR4320152). This is GLERL contribution no. 1921 and CIGLR contribution no. 1144.

\section{DATA AVAILABILITY STATEMENT}

The data that support the findings of this study are openly available in University of Michigan's Deep Blue data repository at https://doi. org/10.7302/z2t151wj.

\section{ORCID}

Peter J. Alsip (D) https://orcid.org/0000-0002-9830-914X

\section{REFERENCES}

ACRCC (2016). Asian Carp Action Plan for Fiscal Year 2017. Retrieved from https://asiancarp.us/PlansReports.html

Anderson, K. R., Chapman, D. C., \& Hayer, C.-A. (2016). Assessment of dreissenid biodeposits as a potential food resource for invasive Asian carp. Biolnvasions Records, 5, 251-257.

Anderson, K. R., Chapman, D. C., Wynne, T. T., Masagounder, K., \& Paukert, C. P. (2015). Suitability of Lake Erie for bigheaded carps based on bioenergetic models and remote sensing. Journal of Great Lakes Research, 41, 358-366.

Anderson, K. R., Chapman, D. C., Wynne, T. T., \& Paukert, C. P. (2017). Assessment of phytoplankton resources suitable for bigheaded carps in Lake Michigan derived from remote sensing and bioenergetics. Journal of Great Lakes Research, 43, 90-99.

Bartell, S. M., Breck, J. E., Gardner, R. H., \& Brenkert, A. L. (1986). Individual parameter perturbation and error analysis of fish bioenergetics models. Canadian Journal of Fisheries and Aquatic Sciences, 43, 160-168.

Boros, G., Mozsár, A., Vitál, Z., Nagy, S., \& Specziár, A. (2014). Growth and condition factor of hybrid (Bighead Hypophthalmichthys nobilis 
Richardson, 1845 x silver carp H. molitrix Valenciennes, 1844) Asian carps in the shallow, oligo-mesotrophic Lake Balaton. Journal of Applied Ichthyology, 30, 546-548.

Bottrell, H. H., Duncan, A., Gliwicz, Z. M., Grygierek, E., Herzig, A., Hillbricht-Ilkowska, A., ... Weglenska, T. (1976). A review of some problems in zooplankton production studies. Norwegian Journal of Zoology, 24, 419-456.

Bowen, S. H., Lutz, E. V., \& Ahlgren, M. O. (1995). Dietary protein and energy as determinants of food quality: Trophic strategies compared. Ecology, 76, 899-907.

Bowie, G. L., Mills, W. B., Porcella, D. B., Campbell, C. L., Pagenkopf, J. R., Rupp, G. L., ... Chamberlin, C. E. (1985). Rates, constants, and kinetics formulations in surface water quality modeling (2nd ed.). Athens GA: U.S. Environmental Protection Agency.

Bramburger, A. J., \& Reavie, E. D. (2016). A comparison of phytoplankton communities of the deep chlorophyll layers and epilimnia of the Laurentian Great Lakes. Journal of Great Lakes Research, 42, 1016-1025.

Brandt, S. B., Mason, D. M., \& Patrick, V. E. (1992). Spatially-explicit models of fish growth rate. Fisheries, 17, 23-35.

Breck, J. E. (2008). Enhancing bioenergetics models to account for dynamic changes in fish body composition and energy density. Transactions of the American Fisheries Society, 137, 340-356.

Bukaveckas, P. A., MacDonald, A., Aufdenkampe, A., Chick, J. H., Havel, J. E., Schultz, R., ... Taylor, D. (2011). Phytoplankton abundance and contributions to suspended particulate matter in the Ohio, Upper Mississippi and Missouri Rivers. Aquatic Sciences, 73, 419-436.

Calkins, H. A., Tripp, S. J., \& Garvey, J. E. (2012). Linking silver carp habitat selection to flow and phytoplankton in the Mississippi River. Biological Invasions, 14, 949-958.

Carrick, H. J., Butts, E., Daniels, D., Fehringer, M., Frazier, C., Fahnenstiel, G. L., ... Vanderploeg, H. A. (2015). Variation in the abundance of pico, nano, and microplankton in Lake Michigan: Historic and basinwide comparisons. Journal of Great Lakes Research, 41, 66-74.

Chen, S. (1982). Studies on the feeding spectrum of silver carp and bighead carp fingerling in Lake Donghu (China). Reservoir Fisheries of China, 3, 21-26. (in Chinese).

Chen, C., Beardsley, R. C., \& Cowles, G. (2006). An unstructured grid, finite volume coastal ocean model (FVCOM) system. Oceanography, 19, 78-89.

Chen, P., Wiley, E. O., \& Mcnyset, K. M. (2007). Ecological niche modeling as a predictive tool: Silver and bighead carps in North America. Biological Invasions, 9, 43-51.

Cooke, S. L., \& Hill, W. R. (2010). Can filter-feeding Asian carp invade the Laurentian Great Lakes? A bioenergetic modelling exercise. Freshwater Biology, 55, 2138-2152.

Cooke, S. L., Hill, W. R., \& Meyer, K. P. (2009). Feeding at different plankton densities alters invasive bighead carp (Hypophthalmichthys nobilis) growth and zooplankton species composition. Hydrobiologia, 625 , 185-193.

Coulter, D. P., MacNamara, R., Glover, D. C., \& Garvey, J. E. (2018) Possible unintended effects of management at an invasion front: Reduced prevalence corresponds with high condition of invasive bigheaded carps. Biological Conservation, 221, 118-126.

Cremer, M. C., \& Smitherman, R. O. (1980). Food habits and growth of silver and bighead carp in cages and ponds. Aquaculture, 20, 57-64.

Cuddington, K., Currie, W. J. S., \& Koops, M. A. (2014). Could an Asian carp population establish in the Great Lakes from a small introduction? Biological Invasions, 16, 903-917.

Cuhel, R. L., \& Aguilar, C. (2013). Ecosystem transformations of the Laurentian great Lake Michigan by nonindigenous biological invaders. Annual Review of Marine Science, 5, 289-320.

Currie, W. J. S., Cuddington, K. M. D., Stewart, T. J., Zhang, H., \& Koops, M. A. (2012) Modelling spread, establishment and impact of bighead and silver carps in the Great Lakes. DFO Can. Sci. Advis. Sec. Res. Doc. 2011/113 3848, vi + 74

De Stasio, B. T., Schrimpf, M. B., \& Cornwell, B. H. (2014). Phytoplankton communities in Green Bay, Lake Michigan after invasion by dreissenid mussels: Increased dominance by cyanobacteria. Diversity, 6, 681-704.

Deboer, J. A., Anderson, A. M., \& Casper, A. F. (2018). Multi-trophic response to invasive silver carp (Hypophthalmichthys molitrix) in a large floodplain river. Freshwater Biology, 597-611.

DeGrandchamp, K. L., Garvey, J. E., \& Colombo, R. E. (2008). Movement and habitat selection by invasive Asian carps in a large river. Transactions of the American Fisheries Society, 137, 45-56.

Degrandchamp, K. L., Garvey, J. E., \& Csoboth, L. A. (2007). Linking adult reproduction and larval density of invasive carp in a large river. Transactions of the American Fisheries Society, 136, 1327-1334.

Dong, S., \& Li, D. (1994). Comparative studies on the feeding selectivity of silver carp Hypophthalmichthys molitrix and bighead carp Aristichthys nobilis. Journal of Fish Biology, 44, 621-626.

Fahnenstiel, G. L., \& Carrick, H. J. (1992). Phototrophic Picoplankton in Lakes Huron and Michigan: Abundance, distribution, composition, and contribution to biomass and production. Canadian Journal of Fisheries and Aquatic Sciences, 49, 379-388.

Fahnenstiel, G. L., Chandler, J. F., Carrick, H. J., \& Scavia, D. (1989). Photosynthetic characteristics of phytoplankton communities in lakes Huron and Michigan: P-I parameters and end-products. Journal of Great Lakes Research, 15, 394-407.

Fahnenstiel, G., Nalepa, T., Pothoven, S., Carrick, H., \& Scavia, D. (2010). Lake Michigan lower food web: Long-term observations and Dreissena impact. Journal of Great Lakes Research, 36, 1-4.

Garvey, J. E., Sass, G. G., Trushenski, J., Glover, D., Brey, M. K., Charlebois, P. M., ... Fritts, M. W. (2015) Fishing down the bighead and silver carps: Reducing the risk of invasion to the great lakes. Project Completion Report. U.S. Fish and Wildlife Service and the Illinois Department of Natural Resources.

Görgényi, J., Boros, G., Vitál, Z., Mozsár, A., Várbíró, G., Vasas, G., \& Borics, G. (2016). The role of filter-feeding Asian carps in algal dispersion. Hydrobiologia, 764, 115-126.

Hanson, P. C., Johnson, T. B., Schindler, D. E., \& Kitchell, J. F. (1997). Fish Bioenergetics 3.0 Technical Report WISCU-97-001. Madison, WI: University of Wisconsin, Sea Grant Institute.

Harris, B. S., Ruetz, C. R., Wieten, A. C., Altenritter, M. E., \& Smith, K. M. (2017). Characteristics of lake sturgeon Acipenser fulvescens Rafinesque, 1817 in a tributary of Lake Michigan, USA: Status of the Muskegon River population. Journal of Applied Ichthyology, 33, 338-346.

Hartman, K. J., \& Brandt, S. B. (1995). Estimating energy density of fish. Transactions of the American Fisheries Society, 124, 347-355.

Hecky, R. E., Smith, R. E. H., Barton, D. R., Guildford, S. J., Taylor, W. D., Charlton, M. N., \& Howell, T. (2004). The nearshore phosphorus shunt: A consequence of ecosystem engineering by dreissenids in the Laurentian Great Lakes. Canadian Journal of Fisheries and Aquatic Sciences, 61, 1285-1293.

Herborg, L.-M., Mandrak, N. E., Cudmore, B. C., \& Maclsaac, H. J. (2007). Comparative distribution and invasion risk of snakehead (Channidae) and Asian carp (Cyprinidae) species in North America. Canadian Journal of Fisheries and Aquatic Sciences, 64, 1723-1735.

International Joint Commission. (2018) Second Binational Great Lakes Basin Poll. Retrieved from https://legacyfiles.ijc.org/tinymce/uploa ded/WQB/WQB_Second_Poll_Report.pdf

Irons, K. S., Sass, G. G., McClelland, M. A., \& Stafford, J. D. (2007). Reduced condition factor of two native fish species coincident with invasion of non-native Asian carps in the Illinois River, U.S.A. Is this evidence for competition and reduced fitness? Journal of Fish Biology, $71,258-273$ 
Janetski, D. J., Ruetz, C. R., Bhagat, Y., \& Clapp, D. F. (2013). Recruitment dynamics of age- 0 yellow perch in a drowned river Mouth Lake: Assessing synchrony with Nearshore Lake Michigan. Transactions of the American Fisheries Society, 142, 505-514.

Jerde, C. L., Bampfylde, C. J., \& Lewis, M. A. (2009). Chance establishment for sexual, semelparous species: Overcoming the Allee effect. The American Naturalist, 173, 734-746.

Ji, R., Davis, C., Chen, C., \& Beardsley, R. (2008). Influence of local and external processes on the annual nitrogen cycle and primary productivity on Georges Bank: A 3-D biological-physical modeling study. Journal of Marine Systems, 73, 31-47.

Ke, Z., Xie, P., \& Guo, L. (2008). In situ study on effect of food competition on diet shifts and growth of silver and bighead carps in large biomanipulation fish pens in Meiliang Bay, Lake Taihu. Journal of Applied Ichthyology, 24, 263-268.

Kocovsky, P. M., Chapman, D. C., \& McKenna, J. E. (2012). Thermal and hydrologic suitability of Lake Erie and its major tributaries for spawning of Asian carps. Journal of Great Lakes Research, 38, 159-166.

Kolar, C. S., Chapman, D. C., Courtenay, W. R., Housel, C. M., Williams, J. D., \& Jennings, D. (2007) Bigheaded carps- A biological synopsis and environmental risk assessment. Bethesda, MD: American Fisheries Society.

Li, S. F., Yang, H. Q., \& Lu, W. M. (1980). Preliminary research on diurnal feeding rhythm and the daily ration for silver carp, bighead carp and grass carp. Journal of Fisheries of China, 4, 275-283. (in Chinese).

Luo, J., Hartman, K. J., Brandt, S. B., Cerco, C. F., \& Rippetoe, T. H. (2001). A spatially-explicit approach for estimating carrying capacity: An application for the Atlantic Menhaden (Brevoortia tyrannus) in Chesapeake Bay. Estuaries, 24, 545.

Madenjian, C. P. (1995). Removal of algae by the zebra mussel (Dreissena polymorpha) population in western Lake Erie: A bioenergetics approach. Canadian Journal of Fisheries and Aquatic Sciences, 52, 381-390.

Madenjian, C. P., Bunnell, D. B., Desorcie, T. J., Chriscinske, M. A., Kostich, M. J., \& Adams, J. V. (2012). Status and Trends of Prey Fish Population in Lake Michigan, 2011. Ann Arbor, MI: U.S. Geological Survey, Great Lakes Science Center.

Madenjian, C. P., Pothoven, S. A., Dettmers, J. M., \& Holuszko, J. D. (2006). Changes in seasonal energy dynamics of alewife (Alosa pseudoharengus) in Lake Michigan after invasion of dreissenid mussels. Canadian Journal of Fisheries and Aquatic Sciences, 63, 891-902.

Madenjian, C. P., Rutherford, E. S., Stow, C. A., Roseman, E. F., \& He, J. X. (2013). Trophic shift, not collapse. Environmental Science and Technology, 47, 11915-11916.

Mason, D. M., \& Brandt, S. B. (1996). Effects of spatial scale and foraging efficiency on the predictions made by spatially-explicit models of fish growth rate potential. Environmental Biology of Fishes, 45, 283-298.

Mason, D. M., Goyke, A., \& Brandt, S. B. (1995). A spatially explicit bioenergetics measure of habitat quality for adult salmonines: Comparison between Lakes Michigan and Ontario. Canadian Journal of Fisheries and Aquatic Sciences, 52, 1572-1583.

Mozsár, A., Specziár, A., Battonyai, I., Borics, G., Görgényi, J., Horváth, H., \& Boros, G. (2017). Influence of environmental factors and individual traits on the diet of non-native hybrid bigheaded carp (Hypophthalmichthys molitrix $\times \mathrm{H}$. nobilis) in Lake Balaton. Hungary. Hydrobiologia, 794, 317-332.

Murphy, E. A., \& Jackson, P. R. (2013) Hydraulic and water-quality data collection for the investigation of great lakes tributaries for Asian carp spawning and egg-transport suitability. Scientific Investigations Report 2013-5106. U.S. Geological Survey.

Nalepa, T. F., Fanslow, D. L., \& Lang, G. A. (2009). Transformation of the offshore benthic community in Lake Michigan: Recent shift from the native amphipod Diporeia spp. to the invasive mussel Dreissena rostriformis bugensis. Freshwater Biology, 54, 466-479.
Napiórkowska-Krzebietke, A., Szostek, A., Szczepkowska, B., \& Błocka, B. (2012). Thermal and oxygen conditions in lakes under restoration following the removal of herbivorous and seston-filtering fish. Archives of Polish Fisheries, 20, 39-50.

National Oceanic and Atmospheric Administration (NOAA) Great Lakes CoastWatch Program (2018). Retrieved from https://coastwatch. glerl.noaa.gov/

Nuevo, M., Sheehan, R. J., \& Willis, P. S. (2004). Age and growth of the bighead carp Hypophthalmichthys nobilis (Richardson 1845) in the middle Mississippi River. Archiv für Hydrobiologie, 160, 215-230.

Pendleton, R. M., Schwinghamer, C., Solomon, L. E., \& Casper, A. F. (2017). Competition among river planktivores: Are native planktivores still fewer and skinnier in response to the Silver Carp invasion? Environmental Biology of Fishes, 100, 1213-1222.

Peters, R. H., \& Downing, J. A. (1984). Empirical analysis of zooplankton filtering and feeding rates. Limnology and Oceanography, 29, 763-784.

Pettitt-Wade, H., Wellband, K. W., Heath, D. D., \& Fisk, A. T. (2015). Niche plasticity in invasive fishes in the Great Lakes. Biological Invasions, 17, 2565-2580.

Plumb, J. M., Blanchfield, P. J., \& Abrahams, M. V. (2014). A dynamic-bioenergetics model to assess depth selection and reproductive growth by lake trout (Salvelinus namaycush). Oecologia, 175, 549-563.

Pothoven, S. A., \& Fahnenstiel, G. L. (2013). Recent change in summer chlorophyll a dynamics of southeastern Lake Michigan. Journal of Great Lakes Research, 39, 287-294.

Radke, R. J., \& Kahl, U. (2002). Effects of a filter-feeding fish [silver carp, Hypophthalmichthys molitrix (Val.)] on phyto- and zooplankton in a mesotrophic reservoir: Results from an enclosure experiment. Freshwater Biology, 47, 2337-2344.

Reed, E. M. (2017). Nearshore Zooplankton communities of Lake Michigan and implications for invasibility by Asian carp. Champaign, IL: University of Illinois at Urbana-Champaign.

Rosaen, A. L., Grover, E. A., \& Spencer, C. W. (2012). The costs of aquatic invasive species to Great Lakes States. Retrieved from https ://www.andersoneconomicgroup.com/Portals/0/upload/AEG\%20 Report\%20-\%20AIS\%20Econ\%20Impact-Final.pdf

Rossmann, R. (2006). Results of the Lake Michigan Mass Balance Project: Polychlorinated Biphenyls Modeling Report. Washington, D.C.: U.S. Environmental Protection Agency, EPA/600/R-04/167,2006.

Rowe, M. D., Anderson, E. J., Vanderploeg, H. A., Pothoven, S. A., Elgin, A. K., Wang, J., \& Yousef, F. (2017). Influence of invasive quagga mussels, phosphorus loads, and climate on spatial and temporal patterns of productivity in Lake Michigan: A biophysical modeling study. Limnology and Oceanography, 62, 2629-2649.

Rowe, M. D., Anderson, E. J., Wang, J., \& Vanderploeg, H. A. (2015). Modeling the effect of invasive quagga mussels on the spring phytoplankton bloom in Lake Michigan. Journal of Great Lakes Research, 41, 49-65.

Sampson, S. J., Chick, J. H., \& Pegg, M. A. (2009). Diet overlap among two Asian carp and three native fishes in backwater lakes on the Illinois and Mississippi rivers. Biological Invasions, 11, 483-496.

Sass, G. G., Hinz, C., Erickson, A. C., McClelland, N. N., McClelland, M. A., \& Epifanio, J. M. (2014). Invasive bighead and silver carp effects on zooplankton communities in the Illinois River, Illinois, USA. Journal of Great Lakes Research, 40, 911-921.

Sheng, D., \& Ma, K. (2008). The influence of the hunger upon the Hypophthalmichthys molitrix appearance form. Journal of Zhoukou Normal University, 25, 83-84. (in Chinese).

Smith, D. W. (1989). The feeding selectivity of silver carp, Hypophthalmichthys molitrix Val. Journal of Fish Biology, 34, 819828.

Thomas, S. M., Chick, J. H., \& Czesny, S. J. (2017). Underestimation of microzooplankton is a macro problem: One size fits all zooplankton sampling needs alterations. Journal of Great Lakes Research, 43, 91-101. 
Tumolo, B. B., \& Flinn, M. B. (2017). Top-down effects of an invasive omnivore: Detection in long-term monitoring of large-river reservoir chlorophyll-a. Oecologia, 185, 293-303.

Vanderploeg, H. A., Liebig, J. R., Nalepa, T. F., Fahnenstiel, G. L., \& Pothoven, S. A. (2010). Dreissena and the disappearance of the spring phytoplankton bloom in Lake Michigan. Journal of Great Lakes Research, 36, 50-59.

Vanderploeg, H. A., Pothoven, S. A., Fahnenstiel, G. L., Cavaletto, J. F., Liebig, J. R., Stow, C. A., ... Bunnell, D. B. (2012). Seasonal zooplankton dynamics in Lake Michigan: Disentangling impacts of resource limitation, ecosystem engineering, and predation during a critical ecosystem transition. Journal of Great Lakes Research, 38, 336-352.

Wang, J. Q., Flickinger, S. A., Be, K., Liu, Y., \& Xu, H. (1989). Daily food consumption and feeding rhythm of silver carp (Hypophthalmichthys molitrix) during fry to fingerling period. Aquaculture, 83, 73-79.

Warner, D. M., \& Lesht, B. M. (2015). Relative importance of phosphorus, invasive mussels and climate for patterns in chlorophyll a and primary production in Lakes Michigan and Huron. Freshwater Biology, 60, 1029-1043.

Weiperth, A., Ferincz, A., Kováts, N., Levente, H., Staszny Keresztessy, K., ... Gábor, P. (2014). Effect of water level fluctuations on fishery and anglers' catch data of economically utilised fish species of lake Balaton between 1901-2011. Applied Ecology and Environmental Research, 12, 221-249.

Williamson, C. J., \& Garvey, J. E. (2005). Growth, fecundity, and diets of newly established silver carp in the middle Mississippi River. Transactions of the American Fisheries Society, 134, 1423-1430.
Zánkai, P. N., \& Ponyi, J. E. (1986). Composition, density and feeding of crustacean zooplankton community in a shallow, temperate lake (Lake Balaton, Hungary). Hydrobiologia, 135, 131-147.

Zhang, H., Mason, D. M., Stow, C. A., Adamack, A. T., Brandt, S. B., Zhang, X., ... Ludsin, S. A. (2014). Effects of hypoxia on habitat quality of pelagic planktivorous fishes in the northern Gulf of Mexico. Marine Ecology Progress Series, 505, 209-226.

\section{SUPPORTING INFORMATION}

Additional supporting information may be found online in the Supporting Information section at the end of the article.

How to cite this article: Alsip PJ, Zhang H, Rowe MD, et al. Lake Michigan's suitability for bigheaded carp: The importance of diet flexibility and subsurface habitat. Freshwater Biol.

2019;64:1921-1939. https://doi.org/10.1111/fwb.13382 